
CENTRO UNIVERSITÁRIO - CATÓLICA DE SANTA CATARINA EM JARAGUÁ DO SUL
CURSO DE DIREITO

PESQUISA EM CIÊNCIA JURÍDICA - TRABALHO DE CONCLUSÃO DE CURSO JACIEL KARVAT

O CRITÉRIO DE MISERABILIDADE PARA FINS DE CONCESSÃO DO BENEFíCIO DE PRESTAÇÃO CONTINUADA NA LEI ORGÂNICA DE ASSISTÊNCIA SOCIAL

JARAGUÁ DO SUL 
O CRITÉRIO DE MISERABILIDADE PARA FINS DE CONCESSÃO DO BENEFÍCIO DE PRESTAÇÃO CONTINUADA NA LEI ORGÂNICA DE ASSISTÊNCIA SOCIAL

Trabalho de Conclusão de Curso apresentado como requisito parcial para aprovação na disciplina Pesquisa em Ciência Jurídica - Trabalho de Conclusão de Curso, e obtenção do grau de bacharel em Direito no Centro Universitário Católica de Santa Catarina em Jaraguá do Sul (SC).

Orientadora: Prof ${ }^{a}$ Msc Lucimara Deretti. 


\title{
O CRITÉRIO DE MISERABILIDADE PARA FINS DE CONCESSÃO DO BENEFÍCIO DE PRESTAÇÃO CONTINUADA NA LEI ORGÂNICA DE ASSISTÊNCIA SOCIAL
}

\begin{abstract}
Trabalho de Conclusão de Curso apresentado como requisito parcial para aprovação na disciplina Pesquisa em Ciência Jurídica - Trabalho de Conclusão de Curso, e obtenção do grau de bacharel em Direito no Centro Universitário Católica de Santa Catarina em Jaraguá do Sul (SC).
\end{abstract}

COMISSÃO EXAMINADORA

Prof. Msc. Luiza Landerdahl Christmann Centro Universitário- Católica de Santa Catarina

Prof ${ }^{a}$. Msc. Lucimara Deretti.

Centro Universitário- Católica de Santa Catarina

Profo $^{\circ}$ Esp. Kesley de Moraes Silva Centro Universitário- Católica de Santa Catarina

Jaraguá do Sul, 28 de novembro de 2017. 
Dedico este trabalho primeiramente a Deus, por ser essencial em minha vida, autor do meu destino, meu guia. Ao meu pai Edvino e minha mãe Eleni. 


\section{AGRADECIMENTOS}

À Deus, que se mostrou criador e foi criativo. Seu fôlego de vida em mim me foi sustento e me deu coragem para questionar realidades e propor sempre um novo mundo de possibilidades.

Agradeço a minha mãe Eleni Santos Karvat, heroína quemedeu apoio, incentivo nas horas difíceis, de desânimo e cansaço.

Agradeço ao meu pai Edvino Karvat, que apesar de todas as dificuldades me fortaleceu e para mim foi muito importante.

Meus agradecimentos aos amigos, companheiros de todas as noites, amizades que fizeram parte da minha formação e vão continuar presentes em minha vida.

Agradeço à 5 a $^{\text {a }}$ Promotoria de Justiça da comarca de Jaraguá do Sul em especial ao Dr. Belmiro Hanisch Júnior e seus assessores Eduardo Schroeder eGraciele Kleinubing Dotta, os quais, fizeram parte dessa minha caminhada, me ensinando e compartilhando ideias durante as tardes, nestes quase dois anos de estágio.

Agradeço à minha querida e amável orientadora e mestre Lucimara Deretti, que com paciência e fôlego, conseguiu corrigir os meus textos e por ser uma excelente professora e profissional, a qual me espelho e tenho um grande orgulho.

Agradeço à professora da disciplina de pesquisa em ciência jurídica, Luiza Landerdahl Christmann, por todo o apoio e tempo disponibilizado para as orientações e correções do meu trabalho de conclusão de curso.

Agradeço esta instituição pelo acolhimento e pelo ambiente oferecido aos seus acadêmicos e os profissionais qualificados que disponibiliza para nos ensinar.

Agradeço aos demais professores por proporcionar o conhecimento não apenas racional, mas a manifestação do caráter e afetividade da educação no processo de formação profissional, por tanto que se dedicaram a mim, não somente por terem me ensinado, mas por terem me feito aprender. A palavra mestre, nunca fará justiça aos professores dedicados aos quais sem nominar terão os meus eternos agradecimentos.

Por fim, o meu muito obrigado a todos que de alguma maneira contribuíram com a minha formação acadêmica e principalmente humana. 
"Conheça todas as teorias, domine todas as técnicas, mas ao tocar uma alma humana, seja apenas outra alma humana." 


\section{LISTA DE ABREVIATURAS E SIGLAS}

AGU: Advocacia Geral da União

ADI: Ação Direta de Inconstitucionalidade

Art.: Artigo

BPC: Benefício de Prestação Continuada

CAP'S: Caixas de Aposentadoria e Pensão

CEME: Central de Medicamento

CF: Constituição Federal

DATAPREV: Empresa de Tecnologia e Informações da Previdência Social

FUNABEM: Fundação Nacional do Bem-Estar do Menor

FUNRURAL: Fundo de Assistência ao Trabalhador Rural

IAPAS: Instituto de Administração Financeira da Previdência e Assistência Social INAMPS: Instituto Nacional de Assistência Médica e Previdência Social

INPC:Índice Nacional de Preços ao Consumidor

INPS: Instituto Nacional de Previdência Social

INSS: Instituto Nacional do Seguro Social

LBA: Legião Brasileira de Assistência

LC: Lei Complementar

LOAS: Lei Orgânica da Assistência Social

LOPS: Lei Orgânica da Previdência Social

MPS: Ministério da Previdência Social

RCL: Reclamação

RGPS: Regime Geral de Previdência Social

SINPAS: Sistema Nacional de Previdência e Assistência Social

STF: Supremo Tribunal Federal

STJ: Superior Tribunal de Justiça

SUS: Sistema Único de Saúde

TRF: Tribunal Regional Federal 


\section{RESUMO}

O presente trabalho teve por objetivo estudar o critério de $1 / 4$ (um quarto) do salário mínimo para aferição do benefício de prestação continuada da Lei Orgânica de Assistência Social - LOAS, se tal critério atende o princípio da dignidade da pessoa humana. Nesse sentido, foi proposto o seguinte problema a ser pesquisado: o critério de $1 / 4$ (um quarto) para aferição do benefício de prestação continuada da Lei Orgânica de Assistência Social - LOAS, atende à dignidade humana? Frente a esse questionamento, formulou-se a hipótese que o julgador deve se reportar à Constituição, que pugna pela dignidade da pessoa humana, combate à pobreza e construção de uma sociedade livre, justa e solidária buscando no caso concreto a verificação efetiva e concreta da hipossuficiência do requerente do benefício de prestação continuada, sendo que, a análise da concessão, deve referir-se ao princípio da dignidade da pessoa humana. Nesta senda, o marco teórico utilizado para desenvolvimento da presente pesquisa foi: CANOTILHO, J. J. Gomes. Direito constitucional e teoria da Constituição; IBRAHIM, Fábio Zambitte. Curso de direito previdenciário; KERTZMAN, Ivan. Curso prático de direito previdenciário; MARTINEZ, Wladimir Novaes. Princípios de direito previdenciário; MARTINS, Sergio Pinto. Direito da seguridade social; NUNES, Luiz Antônio Rizzato. O Princípio Constitucional da Dignidade da Pessoa Humana. São Paulo: Saraiva, 2009. O método científico utilizado foi o hipotético-dedutivo. Como embasamento para coleta de dados para o estudo, utilizou-se maioritariamente a técnica da pesquisa bibliográfica, além da técnica de pesquisa documental na apreciação das normas pertinentes à temática proposta. O trabalho foi apresentado em três capítulos de acordo com os objetivos específicos traçados. Primeiramente, foi realizada uma abordagem prévia sobre a evolução histórica da Assistência Social, bem como a própria seguridade social no mundo e no Brasil. Ademais, foi realizada explanação acerca do conceito de Assistência Social. Analisou-se os princípios da Assistência Social. Explorou-se neste capítulo as diretrizes, objetivos e a relação jurídica da Assistência Social com seus assistidos. No segundo capítulo foi feito um estudo sobre a evolução legislativa do benefício de prestação continuada da Lei Orgânica da Assistência Social; prosseguindo, foi feita uma análise sobre o conceito do benefício de prestação continuada. Em remate, analisou-se as características do benefício assistencial, bem como o requerimento do benefício assistencial. Por fim, o terceiro capítulo foi dedicado ao benefício de prestação continuada e o critério de miserabilidade, além de analisar o requisito de miserabilidade do benefício assistencial. Por derradeiro, estudou-se outros critérios de miserabilidade para a concessão do benefício de prestação continuada, analisando-se as implicações decorrentes da divergência de entendimento da administração pública e o poder judiciário. Fechando o terceiro capítulo, foi estudada a (in)conformidade com o princípio constitucional da dignidade humana. Como resultado da pesquisa, restou comprovada a hipótese, onde o julgador deve se reportar à Constituição, quando a análise da concessão do benefício assistencial, reportando-se ao princípio da dignidade da pessoa humana.

Palavras-chaves: Assistência Social. Benefício de Prestação Continuada. Instituto Nacional do Seguro Social. Lei Orgânica da Assistência Social. Critério da Miserabilidade. 
1 INTRODUÇÃO

2 A ASSISTÊNCIA SOCIAL: UM DOS PILARES DA SEGURIDADE SOCIAL.......14

2.1 A EVOLUÇÃO HISTÓRICA DA ASSISTÊNCIA SOCIAL ..................................14

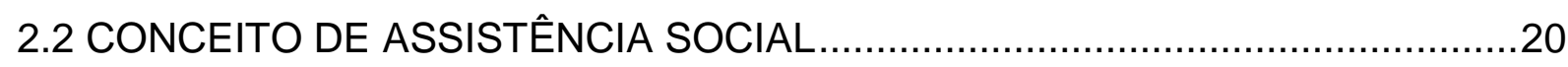

2.3 PRINCÍPIOS DA ASSISTÊNCIA SOCIAL ..................................................22

2.4 DIRETRIZES, OBJETIVOS E RELAÇÃO JURÍDICA DA ASSISTÊNCIA SOCIAL COM OS BENEFICIÁRIOS

3 O BENEFícIO DE PRESTAÇÃO CONTINUADA DA LEI ORGÂNICA DA ASSISTÊNCIA SOCIAL. .33

3.1 EVOLUÇÃO LEGISLATIVA DO BENEFÍCIO DE PRESTAÇÃO CONTINUADA 33 3.2 CONCEITO DO BENEFÍCIO DE PRESTAÇÃO CONTINUADA DA LEI

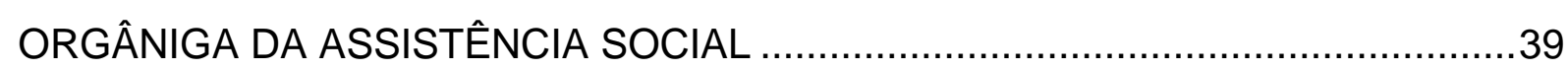

3.3 CARACTERÍSTICAS DO BENEFÍCIO ASSISTENCIAL...................................42

3.4 REQUERIMENTO DO BENEFÍCIO DE PRESTAÇÃO CONTINUADA DA LEI ORGÂNICA DA ASSISTÊNCIA SOCIAL

4 O Benefício de PREstaçÃo CONTINUAdA E O CRITÉrio de MISERABILIDADE: A (IN)CONFORMIDADE COM $O$ PRINCÍPIO CONSTITUCIONAL DA DIGNIDADE DA PESSOA HUMANA .52

4.1 O REQUISITO DA MISERABILIDADE DO BENEFÍCIO DE PRESTAÇÃO CONTINUADA NA LEI ORGÂNICA DE ASSISTÊNCIA SOCIAL.............................52

4.2 OUTROS CRITÉRIOS DE MISERABILIDADE PARA AFERIÇÃO DO BENEFÍCIO DE PRESTAÇÃO CONTINUADA ...................................................58

4.3 IMPLICAÇÕES DECORRENTES DA DIVERGÊNCIA DE ENTENDIMENTO DA ADMINISTRAÇÃO PÚBLICA E O PODER JUDICIÁRIO .......................................60 4.4 A (IN) CONFORMIDADE COM O PRINCÍPIO CONSTITUCIONAL DA

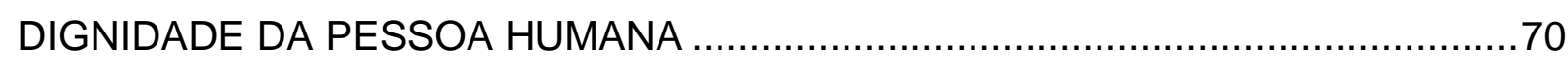

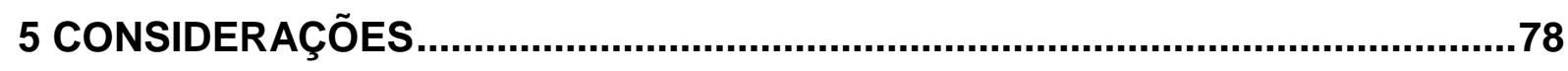

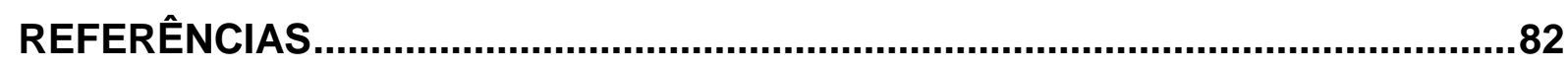




\section{INTRODUÇÃO}

Este estudo teve a finalidade de analisar o critério de miserabilidade previsto no artigo 203, inciso V, da Constituição Federal de 1988, regulamentado pela Lei 8.742, de 07 de dezembro de 1993, qual seja, a renda mensal per capita familiar inferior $1 / 4$ (um quarto) do salário mínimo, conjuntamente examinando os princípios constitucionais acerca desse quesito da renda mensal per capita familiar inferior $1 / 4$ (um quarto) do salário mínimo.

A Constituição Federal garante em seu texto constitucional vida digna aos cidadãos; torna-se imprescindível analisar o contido na Constituição Federal em seu artigo 203, inciso V, regulamentado pela lei 8.742 de 1993, em seu artigo 20 da Lei Orgânica de Assistencial Social (LOAS), no qual firmou uma série de garantias de proteção aos direitos sociais, implicando, assim, maior amparo aos direitos individuais. $O$ benefício de prestação continuada é previsto como garantia à pessoa portadora de deficiência e ao idoso com 65 anos ou mais, desde que comprovem não possuir meios de prover a própria manutenção ou tê-la provida por sua família, neste sentido indagou-se: $O$ critério de $1 / 4$ (um quarto) para aferição do benefício de prestação continuada da Lei Orgânica de Assistência Social (LOAS) atende à dignidade humana?

Entabulou-se a hipótese que o julgador deve se reportar à Constituição, que pugna pela dignidade da pessoa humana, combate à pobreza e construção de uma sociedade livre, justa e solidária buscando no caso concreto a verificação efetiva e concreta da hipossuficiência do requerente do benefício de prestação continuada. $O$ julgador deve estar ciente que a análise dos pressupostos da concessão do benefício assistencial envolve uma reflexão que vai além dos limites objetivos absolutos que a Lei $\mathrm{n}^{\circ}$ - 8.742/1993 e seus decretos regulamentadores originariamente pretenderam estabelecer. Isto porque o exame da necessidade da concessão da prestação assistencial abarca diversas questões fáticas, que devem ser avaliadas caso a caso. Com efeito, os critérios legais podem ser flexibilizados dependendo das condições pessoais do postulante ao benefício. A análise da concessão, deve se reportar ao princípio da dignidade da pessoa humana.

Cabe salientar o marco teórico utilizado para a presente pesquisa, a saber: CANOTILHO, J. J. Gomes. Direito constitucional e teoria da Constituição. 2. ed. Coimbra: Almedina, 1998. IBRAHIM, Fábio Zambitte. Curso de direito 
previdenciário. 22 ed. Niterói: Impetus, 2016. KERTZMAN, Ivan. Curso prático de direito previdenciário. 12 ed. Salvador: JusPodivm, 2015. MARTINEZ, Wladimir Novaes. Princípios de direito previdenciário. 6. ed. São Paulo: LTr, 2015. MARTINS, Sergio Pinto. Direito da seguridade social. 36. ed. São Paulo: Saraiva, 2016.

Ademais, o objetivo geral deste trabalho foi analisar o critério de miserabilidade para a concessão do benefício de prestação continuada e a sua conformidade com o princípio da dignidade da pessoa humana.

Já, especificamente, objetivou-se realizar brevemente um panorama histórico da evolução da assistência social no Brasil, identificando as diretrizes e objetivos da assistência social, assim como, averiguar a evolução legislativa do benefício de prestação continuada da Lei de Assistência Social;analisou-se os princípios constitucionais da dignidade humana, à solidariedade social, à seletividade na prestação dos benefícios e serviços e à universalidade da cobertura do atendimento; buscou-se identificar a divergência acerca do critério de miserabilidade do benefício de prestação continuada contido na LOAS, assim como analisou-se o critério de 1/4 do benefício de prestação continuada da Lei de Assistência Social e suas características.

Para fins de desenvolvimento da pesquisa, foi utilizado o método hipotéticodedutivo, pois se mostra o mais adequado, atendendo as necessidades e características do presente trabalho. Para a sua execução foi utilizada a técnica de pesquisa bibliográfica, assim como a análise da legislação e doutrina pertinente ao tema.

Especificadamente, sobre o desenlace do trabalho e a obtenção dos objetivos específicos. No primeiro capítulo analisou-se o desenvolvimento histórico da assistência social, bem como da seguridade social. Posteriormente, discorreu-se sobre o conceito de assistência social, o qual se encontra no artigo 203 da Constituição Federal de 1988. Nesse passo, foi examinado os princípios da assistência social, os quais estão submetidos aos princípios constitucionais. Por fim, descreveu-se sobre as diretrizes da assistência social que estão no artigo $5^{\circ}$ da Lei Orgânica de Assistência Social, quais sejam, descentralização políticoadministrativa, participação da população e primazia da responsabilidade do Estado na condução da política de assistência social, bem como os objetivos da assistência social. 
No segundo capítulo explicou-se sobre a evolução legislativa do benefício de prestação continuada, também se discorreu sobre o conceito que se deve entender acerca do benefício de prestação continuada, assim como as características do benefício assistencial. Por derradeiro, foi explanado sobre o procedimento do requerimento do benefício assistencial.

Por fim, no terceiro capítulo desse trabalho, tratou-se sobre o critério de miserabilidade do benefício de prestação continuada, da Lei n. 8.742/93 - LOAS. Ou seja, foram verificados os parâmetros trazidos pela lei para a aferição da condição de necessitado da pessoa com deficiência ou do idoso. Ademais, fez-se uma comparação do critério trazido pela LOAS com outros requisitos contidos em leis assistenciais do direito brasileiro. Em seguida, foi realizado comentários sobre algumas implicações decorrentes da divergência de entendimento da Administração Pública, representada pelo Instituto Nacional do Seguro Social - INSS, e do Poder Judiciário sobre o requisito da miserabilidade trazido pela LOAS. Por fim, fechando o terceiro capítulo, foi realizado um estudo sobre a (in)conformidade do critério do benefício de prestação continuada, qual seja $1 \frac{1}{4}$ do salário mínimo, com o princípio da dignidade da pessoa humana.

Tal pesquisa é necessária em virtude da importância jurídica e social do tema, buscando contribuir com o estudo da concessão do benefício de prestação continuada - BPC, ao idoso e ao deficiente físico, analisando a adequação e os requisitos à função do Estado Social e ao princípio da dignidade da pessoa humana. Embora o tema tenha atingido abrangência da Suprema Corte, ainda é bastante controverso. A grande divergência acerca do tema é acarretada pelo entendimento do Instituto Nacional do Seguro Social - INSS de não flexibilizar o critério da miserabilidade trazido pela LOAS para a concessão do benefício de prestação continuada - BPC. Portanto, a autarquia federal considera esse requisito como o único a ser observado para a aferição da necessidade da pessoa com deficiência e do idoso.

Tal situação acarreta grande problema para a sociedade de maneira geral, pois vários idosos ou pessoas com deficiência, que vivem em condições de extrema pobreza, tem seu direito negado em razão de sua renda familiar ultrapassar de forma mínima o valor estabelecido pela LOAS. Existem várias pessoas que não cumprem tal requisito objetivo e simplesmente matemático, no entanto, tais indivíduos fazem jus de forma cristalina ao benefício. 
Em virtude disso, a importância do estudo sobre tal tema reside no fato de possibilitar a investigação dos principais pontos de divergência, bem como os fundamentos que se utiliza para justificar a concessão de tal benefício. Além disso, trata-se de um tema que envolve grande parte da população brasileira, qual seja, os carentes. A LOAS, ao exigir, como critério objetivo, comprovação de renda per capita inferior a $1 / 4$ (um quarto) do salário mínimo, tentou reduzir o rol de beneficiários, ferindo diretamente o princípio da dignidade da pessoa humana. 


\section{A ASSISTÊNCIA SOCIAL: UM DOS PILARES DA SEGURIDADE SOCIAL}

Neste primeiro capítulo será estudada a assistência social que é um dos pilares da seguridade social, abordando seu desenvolvimento histórico, bem como a própria seguridade social e o seu contexto histórico.

Posteriormente, será estudado o conceito de assistência social, o qual foi esculpido no artigo 203 da Constituição da República Federativa do Brasil, sendo posteriormente regulamentado pela Lei Orgânica da Assistência Social a qual definiu no artigo $1^{\circ}$ o conceito de assistência social, que será analisado mais detalhadamente no curso desse capítulo.

$\mathrm{Na}$ sequência, analisa-se os princípios da assistência social, os quais estão submetidos aos princípios constitucionais. Porém, os artigos. 203 e 204, da Constituição Federal, e o art. 4ํㅡㄹ da Lei Orgânica de Assistência Social, têm regras específicas que devem orientar as políticas públicas destinadas à cobertura pela assistência social, pautadas, principalmente, pelo respeito ao princípio da dignidade da pessoa humana.

Nesse passo, será examinado as diretrizes da assistência social que estão no artigo $5^{\circ}$ da Lei Orgânica de Assistência Social, quais sejam, descentralização político-administrativa, participação da população e primazia da responsabilidade do Estado na condução da política de assistência social (BRASIL, 1993).

Por fim, serão estudados os objetivos da assistência social, os quais se encontram esculpidos no artigo 203 da Constituição da República Federativa do Brasil, além de estarem definidos no artigo $2^{\circ}$ da Lei Orgânica de Assistência Social, verificando os principais aspectos da relação jurídica entre o Estado e os assistidos.

\subsection{A EVOLUÇÃO HISTÓRICA DA ASSISTÊNCIA SOCIAL}

Nesta direção, consoante se depreende do teor do artigo 194, da Constituição Federal de 1988 supramencionado, a Seguridade Social abrange as seguintes espécies de direitos: saúde, previdência e assistência social, sendo que, cabe refletir mais acentuadamente o que vem a ser a Assistência Social, visto ser objeto de estudo da presente dissertação.

Um dos principais instrumentos disciplinados pela Ordem Social é a Seguridade Social, que baseada no trabalho propicia o bem-estar e a justiça social. 
O conceito de Seguridade Social se encontra no artigo 194, da Constituição da República Federativa do Brasil de 1988 (BRASIL, 1988), que diz: "O conjunto integrado de ações de iniciativa dos Poderes Públicos e da sociedade destinadas a assegurar os direitos relativos à Saúde a Previdência e a Assistência Social", com o dever Constitucional imposto aos poderes públicos e a sociedade demonstra-se que a solidariedade é o fundamento da seguridade social (SANTOS, 2016).

A seguridade social deve garantir a proteção social, previdência social e o direito a saúde. A seguridade social deve apresentar-se quando o indivíduo não tiver condições de prover seu próprio sustento e de sua família, em razão de doença, invalidez, desemprego ou algum outro motivo que torne necessário a proteção social. A proteção social se dará através do pagamento de um benefício correspondente a sua contingência necessidade dentro de um limite estipulado, além de serviços de assistência a saúde (SANTOS, 2016).

A assistência social, fundada na caridade e, na maioria das vezes conduzida pela Igreja, foi uma das primeiras formas de proteção social. Destarte, também sendo conduzida por instituições públicas (SANTOS, 2016).

Contudo, consoante lições de Fábio Zambitte Ibrahim (2016, p. 01), pode-se dizer que "a proteção social nasceu, verdadeiramente, na família".

A ideia de família já teve um entendimento mais veemente e abrangente em comparação aos nupérrimos. No passado, os indivíduos viviam normalmente em grandes aglomerados familiares, e nesses lugares, considerava-se também como função dos jovens aptos ao trabalho o cuidado com os mais idosos e incapacitados (IBRAHIM, 2016).

$O$ indivíduo que se encontrava em situação de necessidade, como por exemplo, em casos de desemprego, doença e invalidez, socorria-se da caridade dos demais membros da comunidade (SANTOS, 2016).

Segundo Fabio Zambitte Ibrahim (2016, p.02), "infelizmente, a desagregação familiar aviltou e ainda debilita a mais antiga forma de proteção social". Por isso, sistemas protetivos de outra ordem foram adotados pela sociedade, ainda que de modo não claramente perceptível, como o voluntariado de terceiros, o qual acabou por assumir papel fundamental na defesa da existência digna da pessoa humana (IBRAHIM, 2016).

No Brasil, o seguro social iniciou-se através da Santa Casa de misericórdia, como a de Santos em 1534, com o plano de pensão aos empregados que prestava 
serviços de assistência social (IBRAHIM, 2016). Nesta época não existia a interferência do Estado, sendo sua organização de caráter privado, aos poucos através de políticas intervencionistas é que o Estado se apropriou do sistema (MARTINEZ, 2015a).

$\mathrm{Na}$ evolução da Constituição se encontra os primeiros marcos históricos em 1824, no art. 179, inciso XXXI que tratava da Constituição dos socorros públicos ${ }^{1}$. Posterior a isto, no caráter mutualista, foi criado o Montepio Geral dos Servidores do Estado - Mongeral, sendo a primeira entidade de previdência social privada a funcionar (KERTZMAN, 2015).

A Constituição de 1891 foi a pioneira em utilizar a palavra aposentadoria, determinando que a aposentadoria só poderia ser dada aos funcionários públicos em caso de invalidez no serviço da Nação (BRASIL, 1891). Esta regra era válida somente a servidores públicos, no caso de invalidez permanente, tratando não como uma espécie de benefício, mas de compensação. A Lei no 3.724/1919 instituiu o seguro obrigatório de acidentes de trabalho com indenização pelo dano sofrido aos empregados. A contribuição não era revertida pelo Estado, mas à empresas privadas (KERTZMAN, 2015).

O marco da previdência social brasileira foi a publicação da Lei Eloy Chaves, através do Decreto o 4.682/23, com a criação das Caixas de Aposentadorias e Pensões - CAP's, destinadas aos empregadores ferroviários, através das contribuições dos empregadores, dos trabalhadores e do Estado, resguardando aposentaria e pensão aos dependentes (KERTZMAN, 2015).

Através do decreto oํ 4.682/23, com a ampliação do sistema de Caixas de Aposentadorias e Pensão - CAP's, também foram considerados como beneficiários professores de escolas mantidas pelas empresas vinculadas a trabalhadores subordinados, empregadores portuários e marítimos (IBRAHIM, 2016). E mais tarde, em 1928 passou a abranger também os empregadores de empresas de telégrafos e radiotelegráficos. A estrutura organizacional das CAP's era separada por empresas, aonde cada uma possuía a sua (MARTINEZ, 2015a).

\footnotetext{
1 "Os socorros públicos são uma dívida sagrada. A sociedade deve subsistência aos cidadões infelizes, seja fornecendo-lhes trabalho, seja assegurando os meios de existência àqueles que não estão em condições de trabalho (Definição contida no art. 21 da Declaração dos Direitos do Homem e do Cidadão de 1793" (HORVARTH JÚNIOR, 2012, p. 27).
} 
$\mathrm{Na}$ década de 30, por intermédio da criação do Ministério do Trabalho, Indústria e Comércio foi editada a Lei oㅡ 367 de 31 de dezembro de 1936 que criou o Instituto de Aposentaria e Pensões - IAP's, onde eram organizados por categoria profissional, dando forma ao atual sistema previdenciário, visto que este instituto já apresentava um número maior de segurados, superior às caixas de aposentadorias (MARTINS, 2016).

A partir da fusão do sistema de Caixas de Aposentadorias e Pensão - CAP's, ocorreu a expansão em diversas categorias profissionais surgindo os institutos próprios para cada classe, tais como: IAPM - Instituto de Aposentadoria e Pensão Marítimas, em 1933, destinada à associação de empregados de empresas de navegações marítimas e fluviais, abrangendo também a situação dos armadores de pesca e dos pescadores individuais, ou com profissões conexas à indústria da pesca (KERTZMAN, 2015); Instituto de Aposentadoria e Pensão dos Comerciários - IAPC, em 1934, sendo editadas através do Decreto no 2.122 de 9 de abril de 1940 onde englobava a classe de comerciante (KERTZMAN, 2015); Instituto da Aposentadoria e Pensão dos Bancários - IAPB , em 1934, criados aos empregados de banco ou de casas bancárias, sendo reservada apenas para trabalhadores subordinados (KERTZMAN, 2015); Instituto da Aposentadoria e Pensão dos Industriários - IAPI, em 1936, financiado através das contribuições obrigatórias dos empregados e da faculdade de inscrição dos empregadores da Indústria, dando Ihes direito a invalidez, auxílio-doença, e pensão (KERTZMAN, 2015).

Podia existir contribuições complementares, tais como: Instituto de Aposentadoria e Pensão dos Empregados em Transporte de Carga - IAPTEC, criado em 1938, destinada aos segurados das CAP's os trabalhadores avulsos de cargas, arrumações e serviços conexos, os motoristas de praça, carroceiros, carreteiros, cocheiros e carregadores de carrinho de mão, sendo classificados de acordo com o Decreto -Lei no 651/1938 (MARTINEZ, 2015a).

No mesmo ano, através do Decreto o 288 de 23 de fevereiro de 1938, foi criado o Instituto e Previdência e Assistência dos Servidores do Estado - IAPASE, unificado ao Instituto da Previdência dos Funcionários Públicos da União, existente desde 1926, tinha o objetivo realizar assistência aos servidores do Estado, por intermédio de operações em favor dos contribuintes. 
A Constituição de 1934 foi a primeira a estabelecer a tríplice forma de custeio, através das contribuições do Governo, dos empregadores e dos trabalhadores (KERTZMAN, 2015).

A primeira Constituição a tratar da assistência social foi em 1942, através do Decreto Lei $n^{\circ}$ 4.890/42 chamada de Legião Brasileira de Assistência Social - LBA.

A finalidade da LBA era atender as famílias dos pracinhas combatentes da $2^{ }$ Guerra Mundial. Caracterizou-se, inicialmente, por um atendimento materno-infantil. Contudo, a LBA foi crescendo e suas finalidades foram acompanhando as demandas do desenvolvimento econômico e social do Brasil, assim como da população em estado de vulnerabilidade social (GOIÁS, 2000).

Reconhecida como a primeira tentativa de sistematizar as normas de proteção social finalmente na Constituição de 1946 utiliza-se a expressão previdência social encaixada no mesmo contexto da matéria constitucional que versava sobre os direitos do trabalho, estando destinadas à proteção as doenças, invalidez (MARTINS, 2016).

O Ministério do Trabalho e da Previdência Social foi criado em 1960, com o objetivo da unificação dos vários critérios estabelecidos nas diversas IAP's existentes, utilizando sua estrutura (IBRAHIM, 2016). Neste momento da previdência, os trabalhadores rurais e domésticos ainda continuavam excluídos da previdenciária social (MARTINS, 2016).

Em 1967 foram unificadas as IAP's através da criação do Instituto Nacional da Previdência Social - INPS, através do Decreto-Lei nº 72/66 e também foi criado o auxílio-doença (MARTINS, 2016).

Aos trabalhadores rurais, somente na Constituição de 1971 através do FUNRURAL, pela Lei Complementar 11/71, é que passaram a gozar dos direitos previdenciários. E os empregados domésticos somente foram incluídos ao sistema através da Lei no 5.859/72 (IBRAHIM, 2016).

Em 1977 foi instituído o Sistema Nacional de Previdência e Assistência Social - SINPAS, responsável pela integração da assistência social, previdência social das entidades ligadas ao Ministério da Previdência e Assistência Social, contando com a estruturação dos órgãos: Instituto Nacional da Previdência SocialINPS, responsável pela administração dos benefícios (MARTINS, 2016); Instituto da Administração Financeira da Previdência Social - IAPAS, responsável pelas arrecadações, fiscalização e cobranças dos contribuintes e seus demais recursos 
(KERTZMAN, 2015); Instituto Nacional da Assistência Médica da Previdência Social - INAMPS, responsável pela saúde (MARTINS, 2016); Fundação Nacional do BemEstar do Menor - FUNABEM, fundação responsável pela promoção de políticas sociais ao menor (MARTINS, 2016); Central de Medicamentos - CEME, responsável pela distribuição de medicamentos (MARTINS, 2016); Empresa de Processamento de Dados da Previdência Social - DATAPREV, empresa pública responsável pelo gerenciamento do sistema de informação da previdência (MARTINS, 2016).

A partir daí, com o Decreto-Lei oㅜ 7.526/78, criou-se um tipo de instituição da previdência social, o Instituto de Serviços Sociais do Brasil - ISSB, com o objetivo de garantir a cobertura a todos os empregados ativos, tendo um único plano de contribuição e benefício (KERTZMAN, 2015).

Após longos períodos, a Constituição da República Federativa do Brasil de 1988 inclui as três atividades da seguridade social em norma constitucional, trazendo a proteção à saúde, a previdência social e a assistência social (IBRAHIM, 2016). Através desta imposição na norma constitucional, em 1990 a Lei no 8.029/90 criou o Instituto Nacional de Seguros Social - INSS, atrelado ao Instituto Nacional da Previdência Social - INSP, sendo responsáveis pela administração financeira da Previdência Social (KERTZMAN, 2015).

$\mathrm{Na}$ Constituição Federal de 1988, a assistência social foi tratada, nos artigos 203 e 204. Foi criada a Lei n. 8.742/93 - Lei Orgânica da Assistência Social - LOAS, que versa sobre a organização da assistência social (IBRAHIM, 2016).

A Lei Orgânica da Assistência Social trouxe o denominado Benefício de Prestação Continuada - BPC, assim como várias outras formas de prestações assistenciais tanto em dinheiro como em serviços (KERTZMAN, 2015).

O Decreto n. 1.330, de 8 de dezembro de 1994, regulamentou o BPC. O Decreto n. 1.774, de 8 de dezembro de 1995, regulamentou o Benefício de Prestação Continuada devido a pessoa com deficiência e ao idoso, revogando o Decreto n. 1.330, de 8 de dezembro de 1994 (KERTZMAN, 2015).

A Legião Brasileira da Assistência Social foi extinta pela Medida Provisória n. 813 em $1^{\circ}$ de janeiro de 1995, que foi convertida na Lei n. 9.649/98 (IBRAHIM, 2016).

O Decreto n. 6.214, de 26 de setembro de 2007, passou a regulamentar o BPC, revogando o Decreto n. 1.774, de 8 de dezembro de 1995 (IBRAHIM, 2016). 
Diante disso, após ter sido perscrutado sobre a evolução histórica da assistência social em nosso país, e ter trazido em seu bojo a grande evolução que a assistência social passou para chegar ao atual modelo editado na Lei n. 8.742/93, a Lei Orgânica da Assistência Social - LOAS faz-se necessário apresentar em linhas abaixo mais especificadamente sobre o conceito de assistência social.

\subsection{CONCEITO DE ASSISTÊNCIA SOCIAL}

A Assistência Social tem por desígnio a garantia de acesso a pecúlios mínimos e provimento de condições para atender circunstâncias sociais e estimular a universalização dos direitos sociais. Consoante entendimento de Mendes e Branco (2014, p. 663), essa área da seguridade destina-se a:

Garantir o sustento, provisório ou permanente dos que não têm condições para tanto. Sua obtenção caracteriza-se pelo estado de necessidade de seus destinatários e pela gratuidade do benefício, uma vez que, para seu recebimento, é indiferente que a pessoa contribua ou não com a seguridade social.

Através dela, demanda proteger todas as pessoas que, não dispondo de capacidade econômica para contribuir, precisem de amparo da Assistência Social e não figurem no rol de segurados obrigatórios da Previdência Social. A definição legal de Assistência Social está inserida no artigo 1ํㅡㄹ da Lei no 8.742/1993 - LOAS (BRASIL, 1993):

Art. 1ํ A assistência social, direito do cidadão e dever do Estado, é Política de Seguridade Social não contributiva, que provê os mínimos sociais, realizada através de um conjunto integrado de ações de iniciativa pública e da sociedade, para garantir o atendimento às necessidades básicas.

A assistência social irá cuidar de uma maneira geral dos hipossuficientes, concedendo um benefício previsto por lei àqueles que nunca contribuíram para o sistema da seguridade social. Dessa forma, constitui garantia de amparo social pelo Estado aos necessitados em casos de deficiência ou idosos com mais de 65 (sessenta e cinco) anos de idade para sobreviverem. Para Martinez (2015a, p. 28), ela representa: 
[...] um conjunto de atividades particulares e estatais direcionadas para 0 atendimento dos hipossuficientes, consistindo os bens oferecidos em pequenos benefícios em dinheiro, assistência à saúde, fornecimento de alimentos e outras pequenas prestações. Não só complementa os serviços da Previdência Social, como a amplia, em razão da natureza da clientela e das necessidades providas.

Tavares (2014, p. 18) define a assistência social como "[...] um plano de prestações sociais mínimas e gratuitas a cargo do Estado para prover pessoas necessitadas de condições dignas de vida".

Frederico Amado (2009, p. 49-50) assim conceitua a assistência social:

É possível definir a assistência social como as medidas públicas (dever estatal) ou privadas a serem prestadas a quem delas precisar, para 0 atendimento das necessidades humanas essenciais, de índole não contributiva direta, normalmente funcionando como um complemento ao regime de previdência social, quando este não puder ser aplicado ou se mostrar insuficiente para a consecução da dignidade humana.

Para Franklin Alves Felipe (apud TAVARES, 2014, p.16):

Ao lado do seguro social previdenciário, o Estado presta também assistência social em certas circunstâncias (velhice, doença etc.), em caráter normalmente geral e de forma voluntária, posto que não retribui, nesses casos, contribuições recebidas.

Em princípio, apenas farão jus às medidas assistencialistas as pessoas não cobertas por um regime previdenciário ou assistidas pela família, uma vez que estas já gozam de proteção. Nessa senda, há de se ressaltar que a responsabilidade pelo sustento das pessoas é, inicialmente, do círculo familiar e apenas supletivamente pelo Estado, tal como prescrevem os artigos 229 e 230 da Constituição Federal de 1988 (ANDRADE, 2014).

Portanto, tem-se a previdência que ampara os trabalhadores segurados, os quais contribuem para fazer jus aos benefícios e a assistência que direciona seus serviços aos carentes e necessitados, os quais não contribuem por falta de recursos. Importante frisar que a situação de carência deve ser sinônimo de miserabilidade, o beneficiário não pode receber renda per capita superior a 1/4 (um quarto) do salário mínimo, sendo este tema que será definido e abordado mais adiante (IBRAHIM, 2016).

Dessa forma, como visto em linhas acima, o conceito de assistência social está cabalmente estabelecido no artigo $1^{\circ}$ da Lei de Orgânica de Assistência Social- 
LOAS, o que basicamente estabelece que os serviços assistências serão prestados aos carentes e necessitados, os quais não contribuem devido sua hipossuficiência financeira. Por derradeiro, cabe trazer no próximo tópico os princípios que norteiam a assistência social, garantindo sua eficaz forma de funcionamento com os seus beneficiários.

\title{
2.3 PRINCÍPIOS DA ASSISTÊNCIA SOCIAL
}

As ações da assistência social, segundo Tavares (2014), são pautadas, mormente, nos princípios da gratuidade e da seletividade. Pela gratuidade, entendese que o benefício não necessita estar vinculado a sistema previdenciário, ou seja, o indivíduo terá acesso às prestações assistenciais mesmo sem contribuir para a seguridade social. Já a seletividade tem como sustentáculo a necessidade de contribuição a seguridade social.

Dotados de valores morais, políticos e jurídicos, os princípios representam o ponto de partida de toda a dogmática jurídica. Berclaz (2002, p. 03) aduz:

\begin{abstract}
Para sustentar que os princípios gerais são normas os argumentos vêm a ser dois, e ambos válidos: antes de mais nada, se são normas aquelas das quais os princípios gerais são extraídos, através de um procedimento de generalização sucessiva, não se vê por que não devam ser normas também eles: se abstraio de espécies animais obtenho sempre animais, e não flores ou estrelas. Em segundo lugar, a função para a qual são abstraídos e adotados é aquela mesma que é cumprida por todas as normas, isto é, a função de regular um caso.
\end{abstract}

Berclaz (2002, p. 03) ainda explicita que:

(...) conhecer as normas jurídicas sem a adequada compreensão dos princípios que as informam é mais ou menos como conhecer as árvores sem conhecer a própria floresta, ou seja, conhecer o particular sem ter a noção do que seja o todo, primar pela individualidade em detrimento do conjunto.

Diante do considerado relevo dos princípios para hermenêutica jurídica, os que compõem a assistência social, estão expressos no artigo $4^{\circ}$ da Lei Orgânica da Assistência Social - LOAS, quais sejam: 
I - supremacia do atendimento às necessidades sociais sobre as exigências de rentabilidade econômica;

II - universalização dos direitos sociais, a fim de tornar o destinatário da ação assistencial alcançável pelas demais políticas públicas;

III - respeito à dignidade do cidadão, à sua autonomia e ao seu direito a benefícios e serviços de qualidade, bem como à convivência familiar e comunitária, vedando-se qualquer comprovação vexatória de necessidade; IV - igualdade de direitos no acesso ao atendimento, sem discriminação de qualquer natureza, garantindo-se equivalência às populações urbanas e rurais;

$\mathrm{V}$ - divulgação ampla dos benefícios, serviços, programas e projetos assistenciais, bem como dos recursos oferecidos pelo Poder Público e dos critérios para sua concessão (BRASIL, 1993).

Fabio Zambitte Ibrahim (2016, p. 13), assim define o propósito da assistência social: "preencher as lacunas deixadas pela previdência social, já que esta, como se verá, não é extensível a todo e qualquer indivíduo, mas somente aos que contribuem para o sistema, além de seus dependentes".

O artigo 4을 da Lei n. 8.742/93, exposto acima, traz os princípios da assistência social $^{2}$. Lilian de Castro Souza (2016, p. 18) afirma que são esses "cinco princípios que devem orientar as políticas e ações de assistência social, que podem ser considerados seus preceitos fundamentais".

Com base no princípio da supremacia do atendimento às necessidades sociais sobre as exigências de rentabilidade, verifica-se que o que realmente importa na assistência social é o atendimento às necessidades sociais, ou seja, não se deve pensar em obtenção de lucro para a realização dos seus fins almejados (IBRAHIM, 2016).

O princípio da universalização dos direitos sociais tem como finalidade tornar o destinatário da ação assistencial acessível para as demais políticas públicas. Em outras palavras, os direitos sociais também devem ser garantidos a todos os indivíduos participantes de políticas assistenciais de forma a possibilitar a ampla efetivação e participação dos indivíduos economicamente hipossuficientes na sociedade (MARTINS, 2016).

O princípio do respeito à dignidade do cidadão, baseado no princípio constitucional da dignidade da pessoa humana, é entendido como a vedação de qualquer comprovação vexatória de necessidade. Deve-se respeitar a autonomia do cidadão, o seu direito ao benefício e seu direito a serviços de qualidade, bem como a

\footnotetext{
2 "Princípios baseados nos estudos realizados por Sergio Pinto Martins na obra Direito da seguridade social" (MARTINS, 2016, p. 479-480).
} 
conveniência familiar e comunitária (SOUZA, 2016), sendo que este princípio será estudo mais detidamente no terceiro capítulo desta pesquisa.

Já o princípio da igualdade de direitos no acesso ao atendimento, refere-se à garantia da equivalência de direitos entre às populações urbanas e rurais. Não poderá haver qualquer tipo de discriminação entre os indivíduos necessitados (MARTINS, 2016).

Por fim, o princípio da ampla divulgação das prestações assistenciais que trás a ampla divulgação dos benefícios, serviços, programas e projetos assistenciais realizados, bem como dos recursos oferecidos e dos critérios para a sua concessão (MARTINS, 2016).

É importante observar que a assistência social não tem caráter universal, pois não atinge a todos, apenas, àqueles indivíduos economicamente hipossuficientes.

Assim, entendido os princípios da assistência social os quais vem esculpido no artigo 4 da Lei Orgânica de Assistência Social - LOAS, necessário trazer a exposição das diretrizes da assistência social, as quais vêm destacadas no artigo 5ำ da Lei Orgânica de Assistência Social - LOAS, bem como, os objetivos da assistência social, os quais se encontram descrito no artigo $2^{\circ}$ da LOAS e por fim, a relação jurídica da assistência social com seus assistidos.

\subsection{DIRETRIZES, OBJETIVOS E RELAÇÃO JURÍDICA DA ASSISTÊNCIA SOCIAL COM OS BENEFICIÁRIOS}

Consoante ensinamento de Sergio Pinto Martins (2016, p. 480), diretriz significa "uma linha reguladora, um traçado, um caminho a seguir. Envolve direção, rumo, sentido, uma conduta ou procedimento a ser seguido".

As diretrizes da assistência social encontram-se elencadas no artigo $5^{\circ}$ da Lei 8.742/1993 (BRASIL, 1993), in verbis:

Art. 5ำ A organização da assistência social tem como base as seguintes diretrizes:

I - descentralização político-administrativa para os Estados, o Distrito Federal e os Municípios, e comando único das ações em cada esfera de governo;

II - participação da população, por meio de organizações representativas, na formulação das políticas e no controle das ações em todos os níveis;

III - primazia da responsabilidade do Estado na condução da política de assistência social em cada esfera de governo. 
A primeira diretriz é a descentralização político-administrativa. A legislação federal é quem determina as normas gerais da assistência social. Entretanto, a coordenação e a execução dos programas é de responsabilidade dos Estados e dos Municípios, e serão auxiliados pelas entidades beneficentes e de assistência social (MARTINS, 2016).

No que tange a participação da população, tem-se que será realizada por meio de organizações, incluindo-se os sindicatos, na qual serão responsáveis pela formulação de políticas assistenciais, como também pelo controle das ações em todos os níveis (KERTZMAN, 2015).

Ademais, a primazia da responsabilidade do Estado na condução da política de assistência social é facultado aos Estados e ao Distrito Federal vincular até 0,5 (zero vírgula cinco) por cento de sua receita tributária líquida a programas de apoio à inclusão e promoção social, sendo proibida a aplicação desses recursos no pagamento de despesas com pessoal e encargos sociais, no serviço da dívida, assim como em qualquer outra despesa corrente não vinculada diretamente aos investimentos ou ações apoiados (MARTINS, 2016).

Nessa linha, complementando as diretrizes, os objetivos da assistência social são os esculpidos no artigo 2으 da Lei 8.742/93 - LOAS, que assim descreve:

Art. $2^{\circ} \mathrm{A}$ assistência social tem por objetivos:

I - a proteção social, que visa à garantia da vida, à redução de danos e à prevenção da incidência de riscos, especialmente:

a) a proteção à família, à maternidade, à infância, à adolescência e à velhice;

b) o amparo às crianças e aos adolescentes carentes;

c) a promoção da integração ao mercado de trabalho;

d) a habilitação e reabilitação das pessoas com deficiência e a promoção de sua integração à vida comunitária; e

e) a garantia de 1 (um) salário-mínimo de benefício mensal à pessoa com deficiência e ao idoso que comprovem não possuir meios de prover a própria manutenção ou de tê-la provida por sua família;

II - a vigilância socioassistencial, que visa a analisar territorialmente a capacidade protetiva das famílias e nela a ocorrência de vulnerabilidades, de ameaças, de vitimizações e danos;

III - a defesa de direitos, que visa a garantir o pleno acesso aos direitos no conjunto das provisões socioassistenciais.

Parágrafo único. Para o enfrentamento da pobreza, a assistência social realiza-se de forma integrada às políticas setoriais, garantindo mínimos sociais e provimento de condições para atender contingências sociais e promovendo a universalização dos direitos sociais (BRASIL, 1993). 
Com base no artigo citado, a proteção social visa a garantia da vida, a redução de danos e a prevenção da incidência de riscos, notadamente, a proteção à família, à maternidade, à infância, à adolescência e à velhice (BRASIL, 1993).

Outro objetivo é o amparo às crianças e adolescentes carentes, sendo realizado de acordo com o percentual destinado pelo Poder Público à saúde na assistência materno-infantil, consoante parágrafo primeiro do artigo 227 da Constituição Federal (BRASIL, 1988).

Além dos objetivos já citados e de acordo com o artigo acima transcrito, almeja-se também a promoção da integração ao mercado de trabalho, assim como a habilitação e a reabilitação das pessoas com deficiência, incentivando sua integração à vida comunitária.

Ademais, é considerado um objetivo, conforme o inciso $V$ do artigo 203 da Constituição Federal, repetido também no artigo 2º, incido I, da Lei n. 8.742/93 LOAS, a garantia de um salário-mínimo de benefício mensal à pessoa com deficiência e ao idoso que comprovem não possuir meios de prover a própria manutenção ou de tê-la provida por sua família (BRASIL, 1993).

$\mathrm{Na}$ assistência social também se almeja a vigilância socioassistencial, buscando analisar territorialmente a capacidade protetiva das famílias, e nela a ocorrência de vulnerabilidade, ameaças, vitimizações e danos. Ademais, busca-se a defesa dos direitos que garantem o pleno acesso ao conjunto das provisões socioassistenciais (KERTZMAN, 2015).

Baseado no artigo $7^{\circ}$, XXV, da Constituição Federal, tem-se outra regra da assistência social, qual seja, o Estado deverá oferecer assistência gratuita em creches e pré-escolas aos filhos e dependentes, desde o nascimento até 5 (cinco) anos de idade (BRASIL, 1988).

Vale frisar que, a assistência social se realiza de forma integrada às políticas setoriais, sempre na busca da amenização da pobreza, garantindo-se o mínimo social e o provimento de condições para atender contingências sociais e à universalização dos direitos sociais.

No que se refere às entidades e organizações de assistência social, deve-se entender como aquelas que prestam atendimento e assessoramento aos beneficiários, bem como as que operam na defesa e garantia de seus direitos, sempre atuando sem fins lucrativos (IBRAHIM, 2016). 
Vale frisar que, as entidades de atendimento são aquelas que, de forma continuada, permanente e planejada, prestam serviços, executam programas ou projetos e concedem benefícios de prestação social básica ou especial, dirigidos às famílias e indivíduos em situações de vulnerabilidade ou risco social e pessoal, respeitadas as deliberações do Conselho Nacional de Assistência Social - CNAS (MARTINS, 2016).

As entidades de assessoramento são aquelas que, de forma continuada, permanente e planejada, prestam serviços e executam programas ou projetos voltados prioritariamente para o fortalecimento dos movimentos sociais e das organizações de usuários, formação e capacitação de lideranças, dirigidos ao público da política de assistência social, e respeitadas as deliberações do CNAS.

Consideram-se entidades de defesa e garantia de direitos as que, de forma continuada, permanente, e planejada, prestam serviços e executam programas e projetos voltados prioritariamente para a defesa e efetivação dos direitos socioassistenciais, construção de novos direitos, promoção da cidadania, enfrentamento das desigualdades sociais, articulação com órgãos públicos de defesa de direitos, dirigidos ao público da política de assistência social, e respeitadas as deliberações do CNAS (SOUZA, 2016).

Considerando que o objeto do presente estudo consiste no critério de miserabilidade do benefício de prestação continuada da Lei Orgânica da Assistência Social, será apresentado adiante a relação jurídica do regime da assistência social com seus assistidos.

Trata-se da relação dotada de peculiaridades que difere das relações estabelecidas pelos outros pilares da seguridade social, quais sejam, a previdência social e a saúde ${ }^{3}$.

Conforme o artigo primeiro da Lei n. 8.742/93, abaixo transcrito:

Art. 1을 A Assistência Social, direito do cidadão e dever do Estado, é política de Seguridade Social não contributiva, que provê os mínimos sociais, realizada através de um conjunto integrado de ações de iniciativa pública e da sociedade, para garantir 0 atendimento às necessidades básicas (BRASIL, 1993).

\footnotetext{
${ }^{3}$ Cabe destacar que foi adotado neste trabalho a abordagem proposta por Wladimir Novaes Martinez que, além da relação jurídica da assistência social, inclui em seus estudos, outras relações, como a relação entre os sujeitos, relação jurídica de ingresso, o custeio, as prestações, questões de hermenêutica, entre outros (MARTINEZ, 2015a).
} 
Percebe-se, a partir do trecho acima, a primeira característica da assistência social, qual seja, a não contributividade. Para o recebimento de qualquer prestação assistencial não há a necessidade de prévia contribuição, isto porque a sua razão de ser está na necessidade dos indivíduos economicamente hipossuficientes (IBRAHIM, 2016).

Além disso, a responsabilidade para a consecução de suas atividades não é apenas responsabilidade do Estado, mas também, é dever de toda a sociedade.

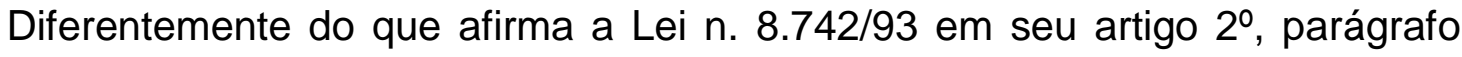
único, no qual consta que "para o enfrentamento da pobreza, a assistência social realiza-se de forma integrada às políticas setoriais, garantindo mínimos sociais e provimento de condições para atender contingências sociais e promovendo a universalização dos direitos sociais" (BRASIL, 1993), não há no que se falar em erradicar ou lutar contra a miséria, pois isso não é tarefa da assistência social e muito menos da seguridade social (KERTZMAN, 2015). O fim colimado é amenizar as condições de subsistência dos protegidos, ou seja, não se pretende enfrentar nem acabar com a hipossuficiência, mas apenas diminuir a necessidade para melhorar a situação do ser humano, conforme o princípio da dignidade da pessoa humana.

É importante destacar, que para a realização da finalidade da assistência social devesse respeitar a capacidade do gestor, ou seja, a capacidade da sociedade, entendida de uma maneira geral, em poder realizar os programas e prestações assistenciais.

As atividades mais frequentes, utilizadas pela Administração Pública nos programas de assistência social são, preferencialmente, as de natureza preventiva. O Estado utiliza o Direito com o intuito de apaziguar as distorções sociais existentes.

Têm-se como sujeitos da relação jurídica da assistência social dois envolvidos, são eles, a pessoa jurídica e a pessoa física. O primeiro é o órgão gestor de direito público ou privado. A pessoa física corresponde ao que a lei denomina de hipossuficiente, que não é destinatário da previdência social (MARTINEZ, 2015a). No que tange ao Benefício de Prestação Continuada da Lei n. 8.742/93, as pessoas físicas descritas são os idosos com mais de 65 anos de idade e as pessoas com deficiência que comprovem não possuir meios de prover a própria manutenção ou de tê-la provida por sua família. 
O objeto ou o rol de prestações desta relação jurídica pode ser de dois tipos: os benefícios em dinheiro e os benefícios em serviços. Tais benefícios são prestações mínimas garantidas por lei para a subsistência do indivíduo (MARTINEZ, 2015b).

Como exemplos de prestações em dinheiro pode-se citar: o benefício de prestação continuada da LOAS para os idosos e pessoas com deficiência, que necessitem do seu recebimento, no valor de um salário mínimo, que em razão de questões de ordem prática, é paga pelo Instituto Nacional do Seguro Social - INSS; o auxílio habitação, que muitos municípios criam para auxiliar os necessitados no que se referem a questões ligadas ao problema da moradia, muitas vezes no valor de metade de um salário mínimo, entretanto, tal quantia depende de cada legislação; o auxílio deslocamento, benefício assistencial em dinheiro destinado à gestante para auxiliar no seu deslocamento, a fim de que realize o pré-natal.

Os benefícios assistenciais em serviços podem ser entendidos como qualquer tipo de prestação de serviço que o Estado oferece ao assistido, como por exemplo, o fornecimento de alimentos, a proteção ao idoso, a proteção à criança e ao adolescente, entre outras tantas.

$\mathrm{Na}$ assistência social não há a ideia de filiação, existe uma denominada relação jurídica de ingresso, na qual inexiste prévia admissão do interessado em alguma entidade protetora para a outorga de prestações. É uma relação intuitus personae, ou seja, de caráter personalíssimo.

No que tange ao início da relação jurídica da assistência social, cabe transcrever trecho do entendimento de Wladimir Novaes Martinez (2015a, p. 190) sobre o assunto:

\footnotetext{
Com o exercício do bem propiciado, nasce a participação e, com ela, a relação jurídica. Automaticamente, enquanto não deferido o pretendido, inexiste a ligação substantiva. Ocorre a ficção autorizadora da pretensão, a ser examinada em processo de instrução administrativa.

Deflagrada a concessão, o requerente torna-se assistido e obtém a prestação enquanto atender os requisitos fixados na lei para o deferimento e a manutenção.
}

Portanto, o início da relação jurídica é o momento em que o indivíduo se torna assistido, ou seja, quando é reconhecido seu estado de necessidade e lhe é deferido o benefício assistencial em dinheiro e/ou serviços. 
Sobre as características das prestações, pode-se identificar a não acumulação dos benefícios em dinheiro, a intransferibilidade de benefícios, a tarifação, imprescritibilidade, a natureza alimentar, a condicionalidade e a temporariedade (MARTINEZ, 2015b).

Conforme as regras de acumulação, somente os benefícios em serviços são acumuláveis. Os benefícios em dinheiro não podem ser acumulados. Também, existem regras de super-direito, que proíbem o recebimento de forma conjunta com prestações previdenciárias.

A característica da intransferibilidade pode ser entendida como a inexistência de direito à transferência do benefício assistencial para os dependentes ou sucessores.

Os benefícios assistenciais são tarifados, ou seja, não existe base de cálculo para se estabelecer o valor do pagamento, sendo ele determinado por lei.

Sobre a característica da imprescritibilidade, conforme Wladimir Novaes Martinez (2015a, p. 191), tem-se que:

[...] a regra básica da prestação assistenciária é ser devida a partir do requerimento e não da instalação do estado justificador. Todavia, beneficiado pelo direito adquirido, são imprescritíveis os direitos, mas prescrevendo as mensalidades até a data de início do pedido.

Outra característica dos benefícios assistenciais é a sua natureza alimentar. Como esse tipo de prestação tem a pretensão de garantir o mínimo existencial para a sobrevivência do indivíduo, seu caráter é essencialmente alimentar. Vale frisar que não se busca manter o indivíduo no mesmo padrão em que se encontrava anteriormente ao estado de necessidade, mas, como já dito, a pretensão é oferecer o mínimo para a sobrevivência do assistido (MARTINEZ, 2015a).

Existe ainda a característica da condicionalidade, tendo em vista ser os benefícios condicionados ao estado de necessidade do assistido. A pessoa tem que se enquadrar nessa condição para fazer jus ao recebimento de benefícios assistenciais. Desaparecendo esse estado de necessidade, extingue-se o direito.

Outra característica que é correlacionada com a descrita no parágrafo anterior, é a temporariedade. A duração da prestação assistencial é, tanto em benefícios em dinheiro como em serviços, de natureza temporária. Em outras palavras, enquanto perdurar a condição de necessitado, o assistido faz jus ao 
benefício. A assistência social serve de trampolim para melhorar a vida do ser humano (MARTINEZ, 2015a).

No que tange às fontes de custeio na assistência social, ela não é verificada de modo direto ou específico, tendo em vista a razão de ser desse pilar da seguridade social, que está ligada a ideia de solidariedade social. A sociedade como um todo arca com os custos (MARTINEZ, 2015a).

Wladimir Novaes Martinez (2015a, p. 191) sobre esse ponto, esclarece a ideia de custeio indireto da assistência social:

Contabilmente, tem-se recomendadas fontes exacionais pré-alocadas, individualizadas, orçamentariamente para tornar possível a fixação dos limites. Quando a entidade beneficente de assistência social é imune à contribuição, recursos usualmente canalizados para a Previdência Social são dessa forma indiretamente consumidos.

De acordo com a Constituição Federal, as verbas estão incluídas, principalmente, no orçamento da seguridade social. Além disso, conforme a Lei n. 8.742/93 - LOAS, as disponibilidades financeiras originam-se dos entes políticos, vertendo as contribuições previstas na Constituição.

No que se refere aos princípios aplicáveis a relação jurídica da assistência social, os principais são: a necessidade; a incapacidade contributiva; disponibilidade de recursos; desproporção entre necessidade e proteção; custeio indireto; facultatividade de ingresso; informalidade de procedimento; igualdade de situação entre os beneficiários; e direito subjetivo às prestações (MARTINEZ, 2015a).

Por fim, no que tange as questões de hermenêutica, ou seja, sobre as regras de interpretação da assistência social, assume grande importância o pressuposto da necessidade. Em razão disso, temos o princípio do in dubio pro misero,que é entendido como, quando houver dúvida a interpretação utilizada deve ser aquela a favor do necessitado (CASTRO; LAZZARI, 2016). Pode ser exemplificado na situação em que o indivíduo só é retirado das políticas assistenciais quando declara a sua situação de não necessitado, ou quando existe algum tipo de denúncia.

Além dele, tem o princípio da norma mais favorável, da interpretação extensiva da lei, e do sentido social da lei. É importante destacar que tais regras nem sempre são seguidas pela jurisprudência pátria.

Diante disso, neste capítulo foi explicado a evolução histórica da assistência social até chegar ao seu atual modelo, bem como demonstrado o conceito de 
assistência social o qual vem esculpido no artigo $1^{\circ}$ da Lei Orgânica de Assistência Social - LOAS, passando em seguida para os princípios que norteiam à Assistência Social. Por fim, demostrado as diretrizes da assistência social, os seus objetivos e a sua relação jurídica com os beneficiários, sendo então, que no próximo capítulo será dado mais ênfase no estudo no que se refere ao Benefício de Prestação Continuada estabelecido na Lei Orgânica de Assistência Social. 


\section{O BenEFícIo de PRESTAÇÃo CONTINUADA DA LEI ORGÂNICA DA ASSISTÊNCIA SOCIAL}

Neste capítulo, realizar-se-á um estudo sobre o benefício de prestação continuada da Lei n. 8.742/93 (Lei Orgânica da Assistência Social), realizando comentários sobre o conceito que se deve entender acerca do benefício prestação continuada que é resguardado pela Constituição Federal a idosos (com 65 anos de idade ou mais) e a pessoas com deficiência de qualquer idade com impedimento de longo prazo, desde que estejam incapacitados para a atividade laborativa e desenvolvimento da vida independente. Além dos requisitos anteriormente citados, ainda se faz necessário que os beneficiários não tenham meios de manter a sua sobrevivência, assim como de tê-la provida por algum ente familiar.

Também será feita uma análise sobre a evolução legislativa do benefício de prestação continuada, trazendo seu soerguimento histórico, sendo que, com o passar dos anos, desde a promulgação da Lei Orgânica de Assistência Social LOAS na década de 90, surgiram muitas outras leis na área da Assistência Social, e com elas, várias incongruências foram sendo encontradas, acarretando muitas divergências no âmbito jurídico, bem como em toda a sociedade. Tal como será feito um estudo acerca das características do amparo assistencial.

Por fim, será explicado qual o procedimento aplicado no que se refere ao requerimento do benefício assistencial, visto que para requerer administrativamente o benefício de prestação continuada, os idosos, com 65 anos ou mais, e as pessoas com deficiência deverão comparecer ao Instituto Nacional Seguro Social ou em uma Agência da Previdência Social - APS. Assim, mesmo sendo um benefício assistencial, o benefício de prestação continuada é concedido pelo INSS, tendo em vista esta Autarquia Federal possuir estrutura própria e organização em âmbito nacional, com condições de atender os necessitados, não havendo razão para manter outra estrutura em paralelo, consoante o princípio da eficiência administrativa (IBRAHIM, 2016).

\subsection{EVOLUÇÃO LEGISLATIVA DO BENEFÍCIO DE PRESTAÇÃO CONTINUADA}

Este item tem como objetivo o estudo da evolução legislativa no que tange ao benefício de prestação continuada. Antes mesmo de existir o Benefício de Prestação 
Continuada, havia a denominada renda mensal vitalícia. Instituída pela Lei n. 6.179/74, essa renda era conhecida à época de amparo previdenciário (MARTINS, 2016).

O amparo previdenciário era equivocadamente vinculado à Previdência Social. Tal erro se constata no que tange ao caráter eminentemente assistencial desse benefício, já desde 1974 (IBRAHIM, 2016).

Quando instituída pela Lei n. 6.179/74, a renda mensal vitalícia correspondia à metade do salário-mínimo vigente à época, e era concedida ao maior de 70 anos ou inválido, definitivamente incapacitado para o trabalho, que não exercesse atividade remunerada ou tivesse rendimento superior ao valor da renda mensal de $60 \%$ (sessenta por cento) do quantum do salário mínimo (MARTINS, 2016).

O artigo 139 da Lei n. 8.213, de 24 de julho de 1991, dispunha que a renda mensal vitalícia continuaria integrando o elenco dos benefícios da Previdência Social (BRASIL, 1991), até que fosse regulamentado o inciso $V$ do artigo 203 da Constituição Federal de 1988.

No artigo 40 da Lei n. 8.742/93 tem-se que, com a implantação do Benefício de Prestação Continuada, ficava extinta a renda mensal vitalícia (BRASIL, 1993).

A eficácia do artigo 139 da Lei n. 8.213/91 foi retirada a partir de $1^{\circ}$ de janeiro de 1996, quando houve a implantação do benefício de prestação continuada, previsto nos artigos 20 e 21 da Lei n. 8.742/93. Além disso, o artigo 15, da Lei n. 9.528/97 revogou o artigo 139, da Lei n. 8.213/91 (MARTINS, 2016).

Portanto, como é possível constatar até o momento, a denominação empregada para o benefício ora em estudo era de amparo previdenciário, conforme a Lei n. 6.179/74. Destarte, foi utilizada a denominação de renda mensal vitalícia, consoante o artigo 139, da Lei n. 8.213/91. Por fim, o artigo 20, da Lei n. 8.742, a Lei Orgânica da Assistência Social, passou a usar a denominação de Benefício de Prestação Continuada.

Como já mencionado em tópicos anteriores, o artigo 20, da Lei n. 8.742/93 estabelece que o benefício de prestação continuada é a garantia de um salário mínimo à pessoa com deficiência e ao idoso com 65 anos ou mais que comprovem não possuir meios de prover a própria manutenção, nem de tê-la provida por sua família. É importante destacar que o benefício assistencial ora em estudo é regulamentado pelo Decreto n. 6.214, de 26 de setembro de 2007. 
A Lei n. 8.742/93, Lei Orgânica da Assistência Social, foi substancialmente alterada pela Lei n. 12.345, de 6 de julho de 2011 e pela Lei n. 12.470, de 31 de agosto de 2011.

No que se refere a idade para considerar a pessoa idosa, tem-se que várias vezes já foi objeto de mudanças. No período de $1^{\circ}$ de janeiro de 1996 a 31 de dezembro de 1997, a idade mínima para o idoso era de 70 (setenta) anos. A partir de $1^{\circ}$ de janeiro de 1998 até 31 de dezembro de 2003, a idade mínima para o indivíduo ser considerado pessoa idosa passou a ser de 67 (sessenta e sete) anos. Após, com a aprovação do Estatuto do Idoso, Lei n. 10.741/03, a partir de $1^{\circ}$ de janeiro de 2004, a idade mínima para ser considerado idoso passou para 65 (sessenta e cinco) anos. A Lei n. 12.435/11 atualizou o artigo 20, da Lei n. 8.742/93, trazendo a idade mínima de 65 (sessenta e cinco) anos para o idoso fazer jus ao benefício assistencial (MARTINS, 2016).

Tratando-se, nesse momento, da pessoa com deficiência, até a edição da Lei n. $12.435 / 11$, alterada posteriormente pela Lei n. $12.470 / 11$, a qual foi novamente alterada pela Lei 13.146, de 06 de julho de 2015, que passou a dispor do novo conceito de deficiência.

Com a publicação do citado diploma legal, a redação dada pela Lei n. 13.146/15 passou a considerar pessoa com deficiência aquela que tem impedimentos de longo prazo de natureza física, intelectual ou sensorial, os quais, em interação com diversas barreiras, podem obstruir sua participação plena e efetiva na sociedade, em igualdade de condições com as demais pessoas (BRASIL, 2015). Considera-se impedimento de longo prazo aquele que produza efeitos pelo prazo mínimo de 2 anos, conforme já exposto precedentemente.

Vale transcrever as lições de Ivan Kertzman (2015, p. 464):

Note-se que tanto o deficiente físico quanto o mental podem receber o benefício assistencial, desde o nascimento. A análise literal do texto legal anterior à alteração promovida pela lei n. 12.470/2011 leva à conclusão de que não era suficiente para a caracterização da deficiência, a incapacidade para o trabalho, sendo, ainda, necessária a incapacidade para a vida independente.

Ao que parece, a redação do $\S 2^{\circ}$, do art. 20 , da lei $8.742 / 93$, promovida pela lei 11.470/2011, corrige a distorção que existia entre a redação da LOAS e a jurisprudência consolidada, ao excluir a exigência da incapacidade para a vida independente para que o segurado seja considerado deficiente. 
Vale ainda transcrever a Súmula n. 29 do dia 13 de fevereiro de 2006, da Turma Nacional de Uniformização de Jurisprudência dos Juizados Especiais Federais, na qual consta que:

Para os efeitos do artigo $20, \S 2^{\circ}$, da Lei n. 8.742 , de 1993, a incapacidade para a vida independente não é só aquela que impede as atividades mais elementares da pessoa, mas também a que impossibilita o indivíduo de prover o próprio sustento (BRASIL, 2006).

Portanto, mesmo antes das alterações mencionadas nos parágrafos anteriores, a jurisprudência do país percebeu que a falta de condições de trabalho já é suficiente para caracterizar a deficiência para fins de concessão de benefício assistencial.

Ademais, a própria Advocacia Geral da União - AGU já tinha elaborado a súmula n. 30, de 9 de junho de 2008, na qual dispõe que:

A incapacidade para prover a própria subsistência por meio do trabalho é suficiente para a caracterização da incapacidade para a vida independente, conforme estabelecido no art. 203, V, da Constituição Federal, e art. 20, II, da lei n. 8.742 de 7 de Dezembro de 1993 (BRASIL, 2008).

Assim, a súmula da AGU desprezou por completo a necessidade adicional de comprovação da incapacidade para a vida independente.

A Lei n. 13.146/15 também possibilitou que os subsídios recebidos pela pessoa com deficiência, que está exercendo atividade laborativa na condição de aprendiz, não seja levada em consideração para fins de cálculo da renda familiar para se aferir o estado de miserabilidade do indivíduo e de seu grupo familiar (IBRAHIM, 2016).

Sobre o assunto tratado no parágrafo anterior, com a nova redação da Lei n. 13.146/15, Ivan Kertzman (2015, p. 466) afirma que "se o deficiente trabalhar como aprendiz, além de não perder o seu benefício assistencial, ainda tem o valor da sua remuneração excluído da renda mensal familiar para concessão de qualquer outro benefício assistencial".

Antes da Lei n. 10.471/03, Estatuto do Idoso, o valor do Benefício de Prestação Continuada - BPC concedido para um primeiro idoso, era considerado na soma da renda mensal familiar para a concessão de um segundo benefício assistencial. Entretanto, tal situação foi modificada pelo parágrafo único do artigo 34 
do Estatuto do Idoso, o qual dispõe que o benefício concedido ao idoso não será computado para os fins do cálculo da renda familiar per capita para a concessão de novos benefício assistenciais (BRASIL, 2003).

Esta nova redação gerou grande divergências e um enorme problema na análise de concessão de benefícios assistenciais. Como o dispositivo somente excluiu os benefícios do idoso da média da renda mensal familiar, em se tratando de família na qual já exista um componente que receba o benefício da LOAS, quando for pessoa com deficiência, este rendimento comporá a renda familiar, impedindo nova concessão assistencial (MARTINS, 2016).

Vale destacar que, em duas decisões de Recursos Extraordinários n. 567.985 e 580.963, no caso concreto, por maioria de votos, o plenário do Supremo Tribunal Federal entendeu pela inconstitucionalidade, declarada de forma incidental, dos artigos 20, parágrafo 3ำ, da Lei Orgânica de Assistência Social (Lei n. 8.742/93) e do parágrafo único do artigo 34, do Estatuto do Idoso (Lei n. 10.471/03) (BRASIL, 2013).

Deixando um pouco de lado o artigo 20, parágrafo 3ํㅡㄹ da LOAS, que trata do critério da miserabilidade para fins de concessão do BPC, tem-se que o parágrafo único do artigo 34, do Estatuto do Idoso gera uma diferenciação não justificada entre os idosos e as pessoas com deficiência. Se a intenção do legislador era beneficiar os idosos que, em regra, passam por muitas dificuldades e obstáculos no país, as pessoas com deficiência enfrentam as mesmas barreiras e dificuldades que o idoso. Portanto, o legislador acabou violando o princípio da isonomia, pois trata iguais de forma diferente na medida em que não estendeu o mesmo direito às pessoas com deficiência (SANTOS, 2016).

Ademais, vale transcrever entendimento de Fábio Zambitte Ibrahim (2016, p. 18) acerca do tema:

O benefício poderá ser pago a mais de um membro da família, desde que comprovadas todas as condições exigidas. Contudo, para o inválido, o valor concedido a outros membros do mesmo grupo familiar passa a integrar a renda, para efeito de cálculo per capita de novo benefício requerido. Já para o idoso, o benefício concedido a qualquer membro da família não será computado para os fins de cálculo da renda familiar. (art. 34, parágrafo único, Lei no 10.741/03). Este tratamento diferenciado foi criado pelo Estatuto do Idoso, enquanto para o deficiente permanece a regra geral da LOAS. No entanto, esta flexibilização da regra de renda per capita traz alguns problemas. Por exemplo: imaginemos um casal de idosos, maiores de 65 anos, sem qualquer fonte de renda, que morem sozinhos. Ambos poderão receber o benefício assistencial, já que para o idoso, um benefício 
de prestação continuada - BPC não será levado em consideração no cálculo da renda per capita. Mas o que dizer da mesma situação, agora com um dos idosos aposentado, recebendo um salário mínimo? Nesta situação, a renda extrapolaria o mínimo fixado na LOAS!

Tal diferenciação de tratamento não se justifica. Ainda que a extensão de direitos sociais deva ser feita com muita cautela, até mesmo em razão do Princípio da Reserva do Possível - haja vista a escassez de recursos financeiros - tamanha discriminação é insustentável. Acredito que, nessas situações, sempre que um idoso for aposentado e outro não, inexistindo outra fonte de renda do casal, e desde que a aposentadoria seja igual ao salário-mínimo, o BPC deva ser concedido para o cônjuge necessitado. Se foi a intenção do Legislador privilegiar o idoso, que se faça isso com igualdade de tratamento. Do contrário, o idoso que contribuiu durante a vida e obteve sua aposentadoria poderá situar-se em estado pior frente àquele que nada verteu ao sistema. Ou assim se procede ou se reconhece a impossibilidade de extensão para ambas as hipóteses, em razão de ausência de custeio (art. 195, §5ํㅡ, CRFB/88).

Corroborando com esta linha de pensamento, vale transcrever lições de Ivan Kertzman (2015, p. 467):

Os legisladores, motivados pela salutar intenção de favorecer os tãosofridos idosos do país, acabaram por criar uma verdadeira aberração legal. Note que o rendimento de uma aposentadoria ou de uma pensão previdenciária, benefícios concedidos um função de contribuições dos segurados, durante vários anos, entram na média de cálculo da renda familiar, enquanto o benefício da LOAS, concedido ao idoso que nunca contribuiu um mês sequer, não compõe a soma.

Esta nova disposição, na prática, vem gerando inúmeras demandas no INSS, uma vez que os aposentados maiores de 65 anos que possuem outro idoso na família têm comparecido às agências do INSS, requisitando o cancelamento da sua aposentadoria para poder beneficiar-se com dois benefícios assistenciais do idoso. Os benefícios de aposentadoria, entretanto, são irrenunciáveis.

Por fim, ressalta-se que a Lei n. 11.435/11 também alterou a antiga definição de família da LOAS, que englobava apenas o conjunto de dependentes previdenciários que viviam sob o mesmo teto. Atualmente, o artigo 20, parágrafo primeiro, da Lei 8.742/1993, considera-se que a família é composta pelo requerente, cônjuge ou companheiro, os pais e, na ausência de um deles, a madrasta ou o padrasto, os filhos solteiros, os irmãos solteiros, enteados solteiros e os menores tutelados, desde que vivam sob o mesmo teto (BRASIL, 1993). 


\subsection{CONCEITO DO BENEFÍCIO DE PRESTAÇÃO CONTINUADA DA LEI ORGÂNIGA DA ASSISTÊNCIA SOCIAL}

O Benefício de Prestação Continuada, também denominado de amparo assistencial, está previsto na Constituição da República Federativa do Brasil de 1988 em seu artigo 203, que assim preceitua:

\footnotetext{
Art. 203. A assistência social será prestada a quem dela necessitar, independentemente de contribuição à seguridade social, e tem por objetivos:

I- a proteção à família, à maternidade, à infância, à adolescência e à velhice; II - o amparo às crianças e adolescentes carentes;

III - a promoção da integração ao mercado de trabalho;

IV - a habilitação e reabilitação das pessoas portadoras de deficiência e a promoção de sua integração à vida comunitária;

V - a garantia de um salário mínimo de benefício mensal à pessoa portadora de deficiência e ao idoso que comprovem não possuir meios de prover à própria manutenção ou de tê-la provida por sua família, conforme dispuser a lei (BRASIL, 1988).
}

Segundo José Afonso da Silva (2010, p. 310-311), o direito à assistência social constitui:

A face universalizante da seguridade social, porque "será prestada a quem dela necessitar, independentemente de contribuição" (art. 203). Nela é que, também, assenta outra característica da seguridade social: a solidariedade financeira, já que os recursos procedem do orçamento geral da seguridade social e não de contribuições específicas de eventuais destinatários (art. 204), até porque estes são impersonalizáveis a priori, porquanto se constituem daqueles que não dispõem de meios de sobrevivência: os desvalidos em geral.

O benefício assistencial no Brasil foi adotado como um dos direitos sociais básicos. Abrangendo o tema, o benefício assistencial, previsto no artigo 203, inciso V, da Constituição Federal, que nas palavras de Fábio Zambitte Ibrahim (2016, p. 12):

Não é benefício previdenciário devido à sua lógica de funcionamento: não carece de contribuição do beneficiário, bastando a comprovação da condição de necessitado. Veio substituir a renda mensal vitalícia, que era equivocadamente vinculada à previdência social, em razão de seu caráter evidentemente assistencial.

Logo, a concessão do benefício da assistência social no Brasil representa a ação do Estado para fornecer aos necessitados, independentemente de terem ou 
não contribuído diretamente aos cofres públicos, valores pecuniários, proporcionando, de certa forma, igualdade em termos de proteção da dignidade humana.

Conforme o artigo 20 da LOAS, tal benefício assistencial pode ser entendido como a garantia de um salário-mínimo mensal à pessoa com deficiência e ao idoso com 65 (sessenta e cinco) anos de idade ou mais, que comprovem não possuir meios de prover a própria manutenção nem de tê-la provida por sua família (BRASIL, 1993).

A pessoa com deficiência é aquela que tem impedimentos de longo prazo de natureza física, mental, intelectual ou sensorial, os quais, em interação com diversas barreiras, podem interferir com sua participação plena e efetiva na sociedade, em igualdade de condições com as demais pessoas. Vale ressaltar que, considera-se impedimento de longo prazo o que produz efeitos pelo prazo mínimo de dois anos (IBRAHIM, 2016).

Sobre a expressão família, consoante parágrafo primeiro do artigo 20 da Lei 8.742/93, é entendida pela composição do requerente, seu cônjuge ou companheiro, os pais e, na ausência de um deles, a madrasta ou o padrasto, desde que vivam sob o mesmo teto. Os irmãos solteiros, os filhos e os enteados solteiros. Por fim, os menores tutelados (BRASIL, 1993).

É importante enfatizar que, todas as pessoas acima mencionadas só serão consideradas como membros da família com a finalidade de prestar a concessão do amparo assistencial, desde que vivam sob o mesmo teto.

Nesse palmilhar, é importante transcrever trecho do entendimento de Fábio Zambitte Ibrahim (2016, p. 20) acerca do tema família, no que refere ao benefício assistencial:

\footnotetext{
Não se deve aqui aplicar o conceito mais amplo de família previsto nas leis $\mathrm{n}^{\circ} 10.219 / 01$ e 10.689/03, que é exposto como "a unidade nuclear, eventualmente, ampliada por outros indivíduos que com ela possuam laços de parentesco, que forme um grupo doméstico, vivendo sob o mesmo teto e mantendo sua economia pela contribuição de seus membros". A LOAS possui conceito específico para os fins do benefício assistencial de prestação continuada, e a tentativa de adoção de conceitos outros, ainda que previstos em leis assistenciais diversas, é evidente tentativa de restringir uma garantia social assegurada pela Constituição.
}

Portanto, não se deve adotar interpretações que ampliem o conceito de família para que não se restrinja uma garantia trazida pela Constituição. Esse conceito 
restritivo trazido pela Lei n. 8.742/93 deve ser utilizado, mesmo sendo falho, tendo em vista permitir que uma pessoa receba o benefício, ainda que de família abastada, se nos basearmos pelo critério de família trazido pelas leis n. 10.219/01 e 10.689/03 (MARTINS, 2015).

No que se refere à expressão não possuir meios de prover a própria manutenção nem de tê-la provida por sua família, tal trecho se refere ao requisito da miserabilidade, ponto central do presente trabalho que será abordado em todos os seus aspectos mais detidamente no próximo capítulo. Nesse momento, basta mencionar que tal benefício será devido ao idoso com mais de 65 (sessenta e cinco) anos de idade ou à pessoa com deficiência, que sejam necessitados ou economicamente hipossuficientes (IBRAHIM, 2016).

Por fim, é importante esclarecer que não se deve confundir os conceitos de pessoa com deficiência com o indivíduo incapaz de prover a própria manutenção nem de tê-la provida por sua família.

Para melhor esclarecer, o conceito de pessoa com deficiência passou recentemente por significativas transformações, o qual, com a promulgação da Lei 13.146/2015 - Estatuto da Pessoa com Deficiência, em seu artigo $2^{\circ}$ descreveu o conceito de pessoa com deficiência:

Considera-se pessoa com deficiência aquela que tem impedimento de longo prazo de natureza física, mental, intelectual ou sensorial, o qual, em interação com uma ou mais barreiras, pode obstruir sua participação plena e efetiva na sociedade em igualdade de condições com as demais pessoas (BRASIL, 2015).

Vale transcrever o entendimento de Ricardo Tadeu Marques da Fonseca (2012, p. 24):

Os impedimentos de caráter físico, mental, intelectual e sensorial são, a meu sentir, atributos, peculiaridades ou predicados pessoais, os quais, em interação com as diversas barreiras sociais, podem excluir as pessoas que os apresentam da participação da vida política, aqui considerada no sentido mais amplo. [...]

Pode-se mencionar, assim, que se o impedimento que a pessoa tem não the traz qualquer dificuldade de integração social, seja no trabalho, seja no desenvolvimento das demais atividades cotidianas, não se enquadra tal pessoa no 
conceito de pessoa com deficiência trazida pelo nosso sistema jurídico (IBRAHIM, 2016).

Entretanto, com relação a incapacidade de prover a manutenção da pessoa com deficiência ou idosa, conforme o $\S 3^{\circ}$ do art. 20 da Lei 8.742/93, "Considera-se incapaz de prover a manutenção da pessoa com deficiência ou idosa a família cuja renda mensal per capita seja inferior a 1/4 (um quarto) do salário-mínimo" (BRASIL, 2011), com a redação dada pela Lei 12.435/2011.

Assim, conforme o dispositivo legal citado, a soma da renda mensal de todos os integrantes dividida pelo número total de membros que compõe o grupo familiar deve ser inferior a um quarto do salário mínimo.

\subsection{CARACTERÍSTICAS DO BENEFÍCIO ASSISTENCIAL}

O benefício de prestação continuada tem diversas características. Como não é benefício previdenciário em razão da lógica de seu funcionamento, e tendo em vista o fim para o qual é destinado, não há o que se falar em contribuição do assistido. Consequentemente, não existe período de carência, sendo apenas necessário a comprovação da condição de hipossuficiência econômica. Ou seja, para fazer jus ao amparo assistencial, o beneficiário não precisa ter contribuído para a Seguridade Social, basta não possuir outra fonte de renda (IBRAHIM, 2016).

Deve-se ter muito cuidado sobre a finalidade e as características do amparo assistencial, pois tal benefício não serve de complementação de renda. O objetivo é tirar as pessoas da miserabilidade, fornecendo uma vida digna.

Conforme o artigo 12, I, da Lei n. 8.742/93, compete à União responder pela concessão e manutenção dos benefícios de prestação continuada, incluindo o seu financiamento. Já a responsabilidade pela operacionalização e execução das concessões é delegada ao Instituto Nacional do Seguro Social - INSS, conforme o artigo 3ํㅡㄹ do Regulamento de Prestação Continuada - RBPC, aprovado pelo Decreto n. 6.214/07 (IBRAHIM, 2016).

Conforme exposto no capítulo anterior, tal fato se deve ao princípio da eficiência administrativa, em razão de que, como o INSS já possui estrutura própria e está organizado em âmbito nacional com condições de atender os necessitados, não há necessidade para manter uma outra estrutura em paralelo (IBRAHIM, 2016). 
O amparo assistencial não pode ser cumulado pelo beneficiário com qualquer outro no âmbito da Seguridade Social ou de qualquer outro regime, exceto os de assistência médica e de pensão especial de natureza indenizatória (MARTINS, 2016).

Ivan Kertzman (2015, p. 469) traz exemplo de possibilidade de cumulação do amparo assistencial com a pensão especial de natureza indenizatória. É o que se vê nas linhas abaixo:

\begin{abstract}
Um exemplo de possibilidade de cumulação é a pensão especial devida aos dependentes das vítimas da hemodiálise de Caruaru/PE, prevista na lei 9.422, de 24 de dezembro de 1996.

Em 1996, ocorreu a morte de 72 pacientes renais submetidos a tratamento de hemodiálise em hospital público em Caruaru, devido à presença de toxinas produzidas por uma microalga encontrada na água utilizada, durante o processo de filtragem do sangue, a Microcystina LR. A água era retirada de um açude. O governo, então, resolveu indenizar os dependentes dos mortos com uma pensão de um salário mínimo.
\end{abstract}

Assim, como explicado no tópico anterior, este benefício é devido aos brasileiros natos e naturalizados idosos com 65 (sessenta e cinco) anos de idade e pessoas com deficiência que tem impedimentos de longo prazo (produz efeitos pelo prazo mínimo de dois anos) de natureza física, mental, intelectual ou sensorial, os quais, em interação com diversas barreiras, podem obstruir sua participação plena e efetiva na sociedade, em igualdade de condições com as demais pessoas (KERTZMAN, 2015).

Vale ressaltar que, tanto os idosos como as pessoas com deficiência devem apresentar hipossuficiência econômica (KERTZMAN, 2015).

Além disso, em virtude do princípio da universalidade, o amparo assistencial também é devido aos estrangeiros, desde que legalmente residentes no país (MARTINS, 2016).

Conforme entendimento de Fábio Zambitte Ibrahim (2016, p. 24):

[...] Se o Brasil acolheu tais estrangeiros, permitindo sua permanência legal no país, é certamente duvidoso que se possa excluí-los da seguridade social brasileira. Especialmente pelo singelo fato destas pessoas, inexoravelmente, participarem do custeio do sistema, haja vista a inclusão das contribuições sociais nos produtos que consomem e nos rendimentos que, porventura, venham a receber.

Segundo Sandra Liebenberg (apud IBRAHIM, 2016, p. 24): 
Por tais argumentos, dentro da realidade nacional, a exclusão de estrangeiros legalmente residentes no país não seria também proporcional, especialmente por vulnerar a abrangência necessária do sistema, fragilizando possível grupo carente somente motivado pela nacionalidade, grupo este formado, com frequência, pelos mais necessitados da seguridade social, como que os colocando em situação de inferioridade frente aos nacionais.

Como nem todo princípio é absoluto, o princípio da universalidade apenas poderia ser mitigado com a finalidade de excluir os estrangeiros necessitados, legalmente residentes no país, em caso de comprovação cabal, por parte da União, de flagrante falência do sistema, e não apenas simples alegações, não havendo, hoje, qualquer motivação sustentável para a não extensão da prestação para essas pessoas. Não há nenhum fundamento razoável que justifique tal discriminação, ainda mais considerando tratar-se de prestação necessária ao mínimo existencial (IBRAHIM, 2016).

Além do princípio da universalidade, o benefício assistencial em questão tem caráter personalíssimo, sendo consequentemente, intransferível. Portanto, tal prestação não gera direitos sucessórios, como também não dá direito a pensão por morte. Com o falecimento do assistido, o benefício assistencial é cancelado, não havendo possibilidade de transmissão desse mesmo benefício, por exemplo, para seus filhos ou cônjuge com a justificativa de que existiria uma relação de dependência. O que pode ocorrer, no caso em exame é talvez o cônjuge ou o filho se enquadrarem nos critérios do benefício assistencial fazendo jus ao recebimento dessa prestação (IBRAHIM, 2016). Entretanto, é importante comentar que, o valor não recebido em vida pelo assistido será pago aos herdeiros, conforme artigo 23 do Regulamento do Benefício de Prestação Continuada, aprovada pelo Decreto $\mathrm{n}$. 6.214/07.

O fato da pessoa com deficiência ou do idoso ser acolhido em instituições de longa permanência, não irá prejudicar o direito desses indivíduos à percepção do benefício de prestação continuada (IBRAHIM, 2016).

Conforme o artigo 35, do Estatuto do Idoso, é facultado às entidades filantrópicas, ou casa lar cobrarem, a título de participação, até 70 (setenta) por cento do benefício assistencial ou previdenciário recebido pelo idoso para auxiliar na manutenção dessas entidades (BRASIL, 2003). É bem verdade que, tal cotização só poderá ser efetivada desde que tais valores sejam utilizados em benefício do idoso. 
Ou seja, para que essa cobrança seja justa, deverá ser direcionada para o sustento do próprio idoso que recebe o benefício.

No que se refere às hipóteses de cessação do pagamento do amparo assistencial, pode-se citar a superação das condições que lhe deram origem, como por exemplo, o indivíduo deixou de ser considerado necessitado. A morte do assistido também é considerada outra hipótese de cessação do benefício, assim como a morte presumida declarada em juízo e a ausência do beneficiário declarada na forma da lei civil. Outra hipótese é a não apresentação da declaração de composição do grupo e renda familiar quando da revisão do amparo assistencial. No que tange ao assistido que teve seu benefício deferido em razão de ser pessoa com deficiência, o não comparecimento ao exame médico pericial acarretará na cessação do pagamento do benefício (IBRAHIM, 2016).

Vale frisar que o benefício de prestação continuada deve ser revisto a cada 2 (dois) anos para avaliação da continuidade das condições que lhe deram origem. $O$ objetivo dessa revisão é evitar fraudes. Ademais, o benefício será cancelado quando constatado qualquer irregularidade na sua concessão ou utilização (IBRAHIM, 2016).

Consoante o Decreto n. 6.214/07, a realização de atividades não remuneradas, a reabilitação, entre outras, não constitui motivo para suspender ou cessar o amparo assistencial, tendo em vista ser função da Assistência Social permitir a participação plena e efetiva do assistido na sociedade em igualdade de condições com as demais pessoas. Também é finalidade desse pilar da Seguridade Social, possibilitar a inserção no mercado de trabalho ao estimular o desenvolvimento das capacidades cognitivas, motoras e educacionais (BRASIL, 2007).

É bem verdade que, havendo a concreta integração do assistido no mercado de trabalho, exercendo atividade remunerada, o benefício assistencial deixará de ser pago, inclusive na condição de microempreendedor individual (IBRAHIM, 2016).

Conforme lições de Sergio Pinto Martins (2016, p. 504):

É mister que o beneficiário não exerça atividade remunerada, não aufira qualquer rendimento superior ao valor da sua renda mensal, nem seja mantido por pessoa de quem dependa obrigatoriamente, não tendo outro meio de prover o sustento próprio.

Vale ainda transcrever as lições de Fábio Zambitte (2016, p. 21) acerca do referido tema: 
Não se deve confundir assistência social com assistencialismo. A proposta do sistema é, além de manter rendimento dignamente mínimo, fornecer aptidão profissional para que o percipiente do benefício possa garantir 0 próprio sustento. Como prevê a Constituição, a ordem social tem como base o primado do trabalho (art. 193).

No que tange a pessoa com deficiência, se for contratada como aprendiz, tal fato não acarretará na suspensão do benefício de prestação continuada. Entretanto, o recebimento concomitante da remuneração e do benefício é limitado a dois anos, como descrito anteriormente (IBRAHIM, 2016).

Destaca-se que, é possível que ocorra uma nova concessão do amparo assistencial ao indivíduo que teve o seu benefício cessado, em razão de ter conseguido trabalho remunerado, mas que sua situação regrediu novamente, voltando ao estado de hipossuficiência econômica, em virtude de ter sido demitido, por exemplo (IBRAHIM, 2016).

Conforme o parágrafo 6을 do artigo 201, da Constituição Federal, a gratificação natalina dos aposentados e pensionistas terá por base o valor dos proventos do mês de dezembro de cada ano (BRASIL, 1988). Portanto, não é devida o abono anual a quem recebe o benefício de prestação continuada, tendo em vista o dispositivo citado mencionar que o abono somente é devido aos aposentados e pensionistas.

Além disso, a Lei n. 8.213/91, que dispõe sobre os planos de benefícios da Previdência Social e da outras providências, em seu artigo 40, consta que é devido o abono anual ao segurado e ao dependente da Previdência Social que, durante o ano, recebeu auxílio-doença, auxílio-acidente ou aposentadoria, pensão por morte ou auxílio-reclusão (BRASIL, 1991). Ou seja, tal dispositivo mostra apenas que o segurado da Previdência Social tem direito ao abono, e não o beneficiário de Assistência Social. Também, não é possível desconto de qualquer contribuição a quem recebe o amparo assistencial.

No que se refere a legitimidade passiva em ações que venham a reivindicar o benefício assistencial, existe bastante divergência. O Tribunal Regional Federal da 4ํ Região chegou a editar a súmula n. 61 do dia 27 de maio de 1999, que foi posteriormente cancelada em 06 de julho de 2004. Essa Súmula estabelecia que "A União e o INSS são litisconsortes passivos necessários nas ações em que seja postulado o benefício assistencial previsto no art. 20 da Lei n. 8.742/93, não sendo caso de delegação de jurisdição federal". No mesmo sentido, encontram-se 
precedentes no Tribunal Regional Federal da $2^{\circ}$ Região (Apelação Cível 2002.51.10.009765-6, Relator Desembargador Sérgio Schwaitzer), como também no mesmo tribunal encontram-se entendimentos em sentido contrário (AC n. 1998.01.00.052633-5/MA, Relator Desembargador Federal Luciano Tolentinho Amaral).

Fábio Zambitte Ibrahim (2016, p. 17), entende que a competência para julgar as ações cujo o tema seja o benefício de prestação continuada, da Lei Orgânica da Assistência Social, seja exclusiva da União. O autor justifica seu pensamento em razão de que "a manutenção da assistência social ser atributo da União, cabendo ao INSS a mera execução". Entretanto, como próprio reconhece o autor, esta posição é minoritária.

O Superior Tribunal de Justiça tem se manifestado pela legitimidade exclusiva do INSS para fins de obtenção do benefício de prestação continuada consoante, por exemplo, em decisões em Recursos Especiais de n. 194.463-SP e n. 204.974-SP.

Neste item, foi possível averiguar as características do Benefício de Prestação Continuada, tal benefício não serve de complementação de renda. O objetivo é tirar as pessoas da miserabilidade, fornecendo uma vida digna, sendo que o BPC após concedido a pessoa idosa com de sessenta e cinco anos de idade ou pessoa com deficiência precisa ser revisto a cada dois anos, com o intuito de evitar fraudes pelos seus beneficiários. Assim, seguindo adiante, será tratado adiante com mais enfoque no requerimento do benefício de prestação continuada da Lei orgânica de assistência social.

\subsection{REQUERIMENTO DO BENEFÍCIO DE PRESTAÇÃO CONTINUADA DA LEI ORGÂNICA DA ASSISTÊNCIA SOCIAL}

Iniciando está tônica que trata sobre o requerimento do amparo assistencial, é importante citar toda a legislação que regulamenta este benefício, quais sejam: o artigo 203, da Constituição Federal de 1988; a Lei n. 8.742/93, Lei Orgânica da Assistência Social (LOAS); a Lei n. 10.741/03, Estatuto do Idoso; o Decreto n. 6.214/07, que regulamenta o Benefício de Prestação Continuada da Assistência Social; o Decreto n. 6.564/08, que altera o regulamento do Benefício de Prestação Continuada; a Portaria Normativa Interministerial MDS/MEC/MS/SEDH n. 18, de 24 de abril de 2007, que cria o programa de acompanhamento e monitoramento do 
acesso e permanência na escola das pessoas com deficiência, beneficiárias do BPC; a Portaria Interministerial MDS/MEC/MS/SEDH n. 1, de 12 de março de 2008, que estabelece os procedimentos e aprova os instrumentos para a adesão ao programa de acompanhamento e monitoramento do acesso e permanência na escola das pessoas com deficiência, beneficiárias do BPC; a Portaria MDS n. 44, de 19 de fevereiro de 2009, BPC na Norma Operacional Básica, NOB/SUAS/2005; a Política Nacional de Assistência Social - PNAS/2004; e por fim, a Portaria Conjunta MDS/INSS n. 1, de 29 de maio de 2009, que institui instrumento para a avaliação da deficiência e do grau de incapacidade de pessoas com deficiência requerentes ao Benefício de Prestação Continuada da Assistência Social - BPC, conforme estabelece o artigo 16, parágrafo $3^{\circ}$, do Decreto n. 6.214/07, alterado pelo Decreto n. 6.564/08.

A Constituição Federal ao dispor acerca do benefício de prestação continuada, apenas tratou do tema, limitando-se a eficácia a norma infraconstitucional, especificamente, a Lei $8.742 / 93$ a defini-lo, bem como a identificação dos sujeitos e dos requisitos objetivos (IBRAHIM, 2016).

Nos termos do art. art. 203, V, da Constituição Federal, o benefício assistencial de prestação continuada apresenta como pressuposto basilar a ausência de condições do beneficiário de prover a sua própria manutenção, seja em razão da idade, seja em razão de uma deficiência (BRASIL, 1988).

A fim de efetivar a norma hierárquica, vez que se trata de norma de eficácia limitada, a LOAS criou critérios objetivos e subjetivos para a concessão do aludido benefício. Assim, a concessão condiciona-se a renda familiar do requerente cumulado com a faixa etária legal ou estado de deficiência, os quais impossibilitem o beneficiário promover sua própria subsistência com recursos próprios ou de seus familiares, necessitando para tanto, a prestação assistencialista (KERTZMAN, 2015).

$\mathrm{O}$ art. 20 da LOAS dispõe, in verbis:

Art. 20. O benefício de prestação continuada é a garantia de um salário mínimo mensal à pessoa com deficiência e ao idoso com 65 (sessenta e cinco) anos ou mais que comprovem não possuir meios de prover a própria manutenção nem de tê-la provida por sua família (BRASIL, 1993).

Nesse ínterim, a Assistência Social restringe-se a amparar pessoas que se encontrem em situação de verdadeira miserabilidade, por essa razão, os requisitos elencados são: uma renda per capita inferior a $1 \frac{1}{4}$ do salário mínimo dos membros 
familiar; 65 anos de idade ou mais, ou padecer de uma deficiência incapacitante para o trabalho (BRASIL, 1993).

Nos ensinamentos de Martins (2016), o requisito etário verifica-se através de documento de identidade apresentado pelo requerente do benefício, bem como desde que comprove o requisito objetivo. Já a deficiência se sujeita a perícia médica pelo INSS, a fim de ser comprovada eventual incapacidade. O requisito de miserabilidade, para ambos, é aferido pela renda grupo familiar que compõe o requerente, conforme reza 0 art. $20, \S 1^{\circ}$, da Lei $n^{\circ} 8.742 / 93$, que define o grupo familiar para fins concessórios:

$\S 1$. Para os efeitos do disposto no caput, a família é composta pelo requerente, o cônjuge ou companheiro, os pais e, na ausência de um deles, a madrasta ou o padrasto, os irmãos solteiros, os filhos e enteados solteiros e os menores tutelados, desde que vivam sob o mesmo teto (BRASIL, 1993).

Desse modo, o conceito de família para a referida lei distingue-se do conceito amplo elencado na Lei 10.219/01 e 10.689/03. Na concepção de Fabio Zambitte Ibrahim (2016), a família para fins assistencialista compreende a unidade mononuclear composta pelo cônjuge, companheiro (a), filhos ou equiparados até 21 anos ou inválidos, pais e irmãos até 21 anos ou inválidos que vivam sob o mesmo teto.

Cabe destacar ainda, que com a publicação do Decreto ํำ 8.805/2016, a inscrição no Cadastro Único de Programas Sociais do Governo Federal - Cadúnico, passou a ser requisito obrigatório para a concessão do benefício. O cadastramento deve ser realizado antes da apresentação de requerimento à unidade do INSS para a concessão do benefício. Já as famílias cadastradas, devem estar com cadastro atualizado para fazer o requerimento no momento da análise da concessão do benefício (BRASIL, 2016).

De acordo com o exposto, a concessão do benefício de prestação continuada condiciona-se a forma cumulativa dos pressupostos legais. Faz-se necessário, portanto, ter a baixa renda e a idade, ou a baixa renda e a deficiência, nos termos definidos pela lei (SANTOS, 2016).

Nessa esteira, com os documentos aptos a comprovar o cumprimento dos requisitos legais, faculta-se ao requerente o pleito concessório do referido benefício 
à Administração Pública no âmbito administrativo, aqui representado pelo Instituto Nacional do Seguro Social - INSS.

Cabe destacar a desnecessidade do esgotamento da via administrativa para propositura de ação pleiteando a concessão de benefício pela Administração Pública, no caso, INSS, a quem compete o deferimento do benefício de prestação continuada, pois, conforme ensina Alexandre de Moraes (2016, p. 159): "inexiste a obrigatoriedade do esgotamento da instância administrativa para que a parte possa acessar o judiciário [...]"

A dispensabilidade do procedimento administrativo embasa-se no princípio do acesso à justiça consagrado na Constituição Federal a todos os cidadãos.

De acordo com os ensinamentos de Alexandre de Moraes (2016, p. 237 238):

\begin{abstract}
O direito à tutela jurisdicional é o direito que toda pessoa tem de exigir que se faça justiça, quando pretenda algo de outra, sendo que a pretensão deve ser atendida por um órgão judicial, através de um processo onde são reconhecidas as garantias mínimas. $O$ acesso dos cidadãos aos tribunais de justiça, à procura de uma resposta jurídica fundamentada a uma pretensão ou interesse determinado, realiza-se pela interposição permanente os órgãos jurisdicionais, cuja missão exclusiva é conhecer e decidir as pretensões, que são submetidas ao conhecimento do órgão judicante, tendo em vista os direitos fundamentais da pessoa.
\end{abstract}

Observa-se inúmeras ações que visam a preservação das garantias mínimas, vez que a LOAS, embora tenha definido a miserabilidade, a concessão restrita à lei e não as peculiaridades de cada caso concreto para fins de aferição enseja à exclusão daqueles que se encontram em situação de penúria social, e de outra forma, a provocação do órgão jurisdicionado para a apreciação da matéria (KERTZMAN, 2015).

Nesse sentido, Silvio de Salvo Venosa (2015, p. 345) "a ação é meio de concretização do direito processual. Sem ela, o direito material torna-se letra morta".

Outrossim, a possibilidade do requerente ingressar com ação petitória constitui-se uma faculdade do agente, conforme ensina Horvath Júnior (2012, p. 139): "o direito previdenciário é um direito público subjetivo. A natureza de direito subjetivo permite o exercício do direito de ação sempre que a relação trilateral entre o titular, o destinatário e o objeto do direito se fizerem presentes [...]". 
Em contrapartida, os atos da Administração Pública regem-se pelo princípio da legalidade, posto que se subordinam à lei, está na como representação da vontade do povo.

Desse modo, Hely Lopes Meirelles (2006, p. 87), conceitua:

\begin{abstract}
A legalidade, como princípio de administração (CF, art. 37, caput), significa que o administrador público está, em toda a sua atividade funcional, sujeito aos mandamentos da lei e as exigências do bem comum, e deles não pode se afastar ou desviar, sob pena de praticar ato inválido e expor-se a responsabilidade disciplinar, civil e criminal, conforme o caso.
\end{abstract}

Corroborado a esse entendimento, Martinez (2015, p.189), ensina que o referido princípio aplica se ao INSS, órgão gestor da previdência, pois "envolve relações entre pessoa de direito público e pessoas de direito privado".

O INSS, a quem se atribui a concessão do benefício de prestação continuada, na qualidade de autarquia federal é definido nas palavras de Di Pietro (2006, p. 423): "[...] como a pessoa jurídica de direito público, criada por lei, com capacidade de autoadministração, para o desempenho de serviço público descentralizado, mediante controle administrativo exercido nos limites da lei".

Dessa feita, embora a Administração Pública, em especial, o INSS deva estrita observância aos critérios consagrados na lei, verifica-se a relativização do requisito objetivo no âmbito judicial, ainda que de forma não pacificada, vez que se busca a os ideários de justiça, sob a hermenêutica da dignidade da pessoa humana (KERTZMAN, 2015).

Dado o exposto, tem-se que os requisitos para a concessão do benefício de prestação continuada encontram-se elencados no artigo 20 da Lei Orgânica de Assistência Social, bem como não possuir meios para prover a própria manutenção ou tê-la provida por sua família denota estado de necessidade, ou seja, que a pessoa não dispõe de condições para garantir o mínimo existencial e, consequentemente, não pode manter sua dignidade (IBRAHIM, 2016).

Por fim, no próximo capítulo, tratar-se-á com exação no que tange o critério de miserabilidade do Benefício de Prestação Continuada, da LOAS, onde verificar-se-á as condições de necessidade trazida pela Lei Orgânica de Assistência Social, bem como os critérios das outras leis de benefícios e, ainda, será demonstrado algumas implicações da divergência de entendimento da Administração Pública e do Poder Judiciário acerca do critério de miserabilidade da LOAS. 


\section{O BENEFícIo de PREstaçÃo CONTINUAdA E O CRITÉRIO DE MISERABILIDADE: A (IN)CONFORMIDADE COM 0 PRINCÍPIO CONSTITUCIONAL DA DIGNIDADE DA PESSOA HUMANA}

Nesse tópico, tratar-se-á mais especificadamente sobre o critério de miserabilidade do benefício de prestação continuada, da Lei n. 8.742/93 - LOAS. Ou seja, serão verificados os parâmetros trazidos pela lei para a aferição da condição de necessitado da pessoa com deficiência ou do idoso.

Ademais, será feita uma comparação do critério trazido pela LOAS com outros requisitos contidos em leis assistenciais do direito brasileiro.

Em seguida, será realizado comentários sobre algumas implicações decorrentes da divergência de entendimento da Administração Pública, representada pelo Instituto Nacional do Seguro Social - INSS, e do Poder Judiciário sobre o requisito da miserabilidade trazido pela LOAS.

Por fim, será trazido ao escopo do estudo a (in)conformidade do critério do benefício de prestação continuada, qual seja $1 \frac{1}{4}$ do salário mínimo, com o princípio da dignidade da pessoa humana.

\subsection{O REQUISITO DA MISERABILIDADE DO BENEFÍCIO DE PRESTAÇÃO CONTINUADA NA LEI ORGÂNICA DE ASSISTÊNCIA SOCIAL}

A Constituição da República Federativa do Brasil de 1988 garante um subsídio mensal de benefício à pessoa com deficiência e ao idoso, que comprovem não possuir meios de garantir à própria manutenção ou de tê-la provida por sua família, conforme previsto a lei (BRASIL, 1988).

Nos termos do artigo $1^{\circ}$ da lei 8.742/1993, a assistência social é definida como um direito de todos os cidadãos, bem como um dever do Estado em prover o mínimo digno àqueles que se encontram num estado de penúria social. Consagra-se como um conjunto integrado de ações de iniciativa pública e privada, a fim de suplantar as principais necessidades do indivíduo, sem o caráter exigível de contraprestação contributiva ao sistema (BRASIL, 1993).

Então, a contingência do benefício de prestação continuada é ser pessoa com deficiência ou idosa e ser necessitado. O critério de miserabilidade é a hipossuficiência econômica com o objetivo de concessão do benefício assistencial 
da Lei n. 8.742/93, e está no parágrafo $3^{\circ}$ do artigo 20. Considera-se incapaz de prover a manutenção da pessoa com deficiência ou idoso, a família cuja renda mensal per capita seja inferior a 1/4 (um quarto) do salário mínimo (BRASIL, 1993).

Observa-se que o critério de miserabilidade é estabelecido pela lei mencionada sob uma interpretação literal da norma que prevê para o cálculo da renda familiar per capita um valor inferior $1 / 4$ do salário mínimo, de outro modo, consiste na comprovação da fragilidade socioeconômica do destinatário de não possuir meios de prover sua própria manutenção e nem tê-la provida por sua família.

A regulamentação do dispositivo mencionado coube ao Decreto n. 6.214/07 para definir as condições de cálculo do rendimento de renda per capita da família do idoso ou da pessoa com deficiência. O inciso IV, do artigo $4^{\circ}$ desse decreto, estabelece que a família incapaz de prover a manutenção da pessoa com deficiência ou do idoso, é aquela cuja renda mensal bruta familiar dividida pelo número de seus integrantes seja inferior a $1 \frac{1}{4}$ (um quarto) do salário mínimo (BRASIL, 2007). $O$ texto dessa disposição repete a ideia do parágrafo único do artigo 34 da Lei n. 10.741/01 Estatuto do Idoso, na qual afirma que o benefício concedido a qualquer membro da família não será computado para os fins do cálculo da renda familiar para concessão do BPC ao idoso (BRASIL, 2001).

$\mathrm{O}$ inciso $\mathrm{VI}$ do mesmo dispositivo, com redação dada pelo Decreto $\mathrm{n}$. 7.617/11, conceitua renda mensal bruta familiar, que é entendida como a soma dos rendimentos brutos auferidos mensalmente pelos membros da família composta por salários, proventos, pensões, pensões alimentícias, benefícios de previdência pública ou privada, comissões, pró-labore, outros rendimentos do trabalho não assalariado, rendimentos do mercado informal ou autônomo, rendimentos auferidos do patrimônio, renda mensal vitalícia e o benefício de prestação continuada, ressalvado o disposto no parágrafo único do artigo 19 do Decreto n. 6.214/07 (BRASIL, 2011).

Como já explicado em tópico anterior, essa situação acarretou muitas divergências e uma grande dificuldade na análise da concessão do BPC. Como tais dispositivos apenas excluíram os benefícios dos idosos da média da renda mensal familiar, no caso de uma família em que já existe uma pessoa que recebe o benefício monetário da LOAS como pessoa com deficiência, essa renda constituirá renda familiar, evitando nova assistência. Esta situação cria uma distinção 
injustificada entre os idosos e as pessoas com deficiência, porque trata o mesmo de uma maneira diferente, violando o princípio da isonomia (LOPES, 2014).

A LOAS consagra o direito ao benefício de prestação continuada aos portadores de deficiência e aos idosos, em contrapartida, estipula o critério de aferição da miserabilidade, os quais, cumulados com a precariedade de manutenção própria do requerente, bem como desses familiares em assisti-lo garante-se a percepção mensal de um salário mínimo.

Considera-se que o artigo 20, parágrafo $3^{\circ}$, da LOAS e o artigo $4^{\circ}$, inciso IV, Decreto no. 6.214/07, para definir as condições para o cálculo do rendimento familiar per capita atribuído ao BPC, se opõem aos princípios da hierarquia das leis e da supremacia da Constituição Federal. Acontece que, quando foi estabelecido o conceito de família incapaz conforme acima explicado, ligado a sua renda bruta, houve clara redução do alcance da proteção pretendida pela Constituição.

Conforme Marisa Ferreira dos Santos (2016, p. 105), o parágrafo 3ํㅡ, do artigo 20, da LOAS é manifestamente inconstitucional:

\begin{abstract}
Não se pode perder de vista que o BPC é aquela parcela de proteção social que se consubstancia em benefício. E a CF quer que esse benefício seja a garantia da manutenção da pessoa com deficiência ou idosa que não tenha ninguém por si. E o fixou em um salário mínimo. O bem-estar social está qualificado e quantificado na CF: qualificado porque se efetiva com a implementação dos direitos sociais; quantificado porque a CF fixou em um salário mínimo a remuneração mínima e o valor dos benefícios previdenciários, demonstrando que ninguém pode ter seu sustento provido com valor inferior. Ao fixar em $1 / 4$ do salário mínimo o fato discriminante para a aferição da necessidade, o legislador elegeu discrimen inconstitucional porque deu aos necessitados conceito diferente de bem-estar social, presumindo que a renda per capita superior a $1 / 4$ do mínimo seria a necessária e suficiente para a sua manutenção, ou seja, quanto menos têm, menos precisam ter! Quantificar o bem-estar social em valor inferior ao salário mínimo é o mesmo que "voltar para trás" em termos de direitos sociais. A ordem jurídica constitucional e infraconstitucional não pode "voltar para trás" em termos de direitos fundamentais, sob pena de ofensa ao princípio do não retrocesso social [...].
\end{abstract}

Portanto, como se pode constatar, ao escolher a renda mensal de uma família per capita de $1 / 4$ (um quarto) do salário mínimo como critério para medir a miserabilidade do indivíduo, o legislador violou a Carta Maior, pois quantificou os benefícios sociais em um valor diferente do estabelecido pela Constituição Brasileira, violando o princípio do retrocesso social.

O princípio do não retrocesso social, também designado de proibição da contrarrevolução social, significa que os direitos sociais e econômicos, como por 
exemplo, direito dos trabalhadores, direito à assistência, direito à educação, uma vez obtidos em determinado grau de realização, passam a constituir uma garantia institucional e um direito subjetivo. Este princípio nada pode fazer contra as crises econômicas. No entanto, limita a reversibilidade dos direitos adquiridos. Portanto, deve-se respeitar a proteção da confiança e da segurança dos cidadãos no âmbito econômico, social e cultural, e do núcleo essencial da existência mínima inerente ao respeito pela dignidade da pessoa humana (CANOTILHO, 1998).

Entretanto, cumpre lembrar, que na via judicial, ocorre a possibilidade do magistrado para consolidar seu convencimento valer-se de outros fatores que comprovem o estado de penúria da parte, bem como a necessidade do benefício de prestação continuada como mínimo vital para a sua subsistência digna. Desprendendo-se, para tanto, do critério legal estritamente absoluto, como já perscrutado neste estudo.

A conclusão a que se chega é que, a proteção dos direitos sociais, adquirida subjetivamente ao longo dos anos, constitui o limite legal para o legislador e, ao mesmo tempo, o dever de continuar com políticas públicas coerentes, com direitos específicos e expectativas subjetivas baseadas.

A violação dos direitos sociais e seu limite legal imposto ao legislador levarão a uma sanção de inconstitucionalidade, tendo em vista as normas aparentemente destrutiva da chamada Justiça social. É precisamente o que acontece com o dispositivo que traz o critério da miserabilidade para a concessão BPC (LOPES, 2014).

Como pode ser visto, o requisito da miserabilidade aduzido pela Lei $\mathrm{n}$. 8.742/93 é controverso, porque o critério estabelecido no parágrafo $3^{\circ}$ do artigo 20 é considerado desatualizado. Esta grande divergência em relação requisito da miserabilidade para a obtenção do BPC, deve-se a um debate sobre a flexibilidade da Lei n. 8.742/93 em relação ao requisito da miserabilidade. Isso significa que procura descobrir se um indivíduo, obviamente em uma situação de necessidade, com uma renda familiar per capita superior $1 / 4$ (um quarto) do salário mínimo, pode ou não pode obter um benefício assistencial (LOPES, 2014).

Assim, depreende-se que o critério objetivo definido na lei infraconstitucional perpetuou-se no tempo, sem a devida adequação as realidades e as necessidades hodiernas. Vale transcrever comentário de Ivan Kertzman (2015, p. 467), no qual se pode constatar a total divergência sobre esse tema: 
Não poderíamos deixar de comentar a forte polêmica jurisprudencial acerca da possibilidade de flexibilização do critério objetivo de definição de pessoa incapaz de prover o próprio sustento ou de tê-lo provido pela família trazido pelo $\S 3^{\circ}$, do art. 20, da Lei $8.742 / 93$ (renda familiar per capita inferior a $1 / 4$ de salário mínimo). O STF havia pacificado o entendimento com base em diversos julgados fundamentados na decisão proferida em sede de ADI $1.232 / 98$ de que é inadmissível a concessão do benefício assistencial a necessitado quando a renda familiar per capita for superior ao estabelecido na Lei. Em recentes decisões, todavia, o Supremo Tribunal começou a alterar o entendimento anteriormente consolidado, julgando ser possível a flexibilização do critério estabelecido pela Lei, se restar provado no processo a falta de condição de sustento. Já o Superior Tribunal de Justiça, em sentido contrário, majoritariamente tem entendido que a comprovação do requisito da renda familiar per capita não superior a $1 / 4$ do salário mínimo não exclui outros fatores que tenham o condão de aferir a condição de miserabilidade da parte autora e de sua família, necessária à concessão do benefício assistencial. A Turma Nacional de Uniformização de Jurisprudência dos Juizados Especiais Federais chegou até a editar a Súmula 11, com a seguinte redação: "A renda mensal, per capita, familiar, superior a $1 / 4$ (um quarto) do salário mínimo não impede a concessão do benefício assistencial previsto no art. 20, § 3ํㅡㄹ da Lei n. 8.742 de 1993, desde que comprovada, por outros meios, a miserabilidade do postulante". A grande polêmica acerca do tema levou ao cancelamento da citada Súmula em 24/04/2006.

Conforme Fábio Zambitte Ibrahim (2016, p. 14) sobre o parâmetro utilizado pela LOAS para a aferição da miserabilidade:

De fato, ainda que o legislador frequentemente utilize-se de parâmetros objetivos para a fixação de direitos, a restrição financeira pode e deve ser ponderada com características do caso concreto, sob pena de condenar-se à morte o necessitado. Ainda que a extensão do benefício somente possa ser feita por lei, não deve o intérprete omitir-se a realidade social.

\section{Fábio Zambitte Ibrahim (2016, p. 14) ainda traz as hipóteses em que são concedidas o benefício de prestação continuada a indivíduos que, embora ultrapassem o requisito objetivo estabelecido na lei, vivem em estado de extrema} pobreza:

Dentro do atual momento pós-positivista do Direito, aliado à reconhecida força normativa da Constituição, os princípios jurídicos constitucionais são dotado também de eficácias interpretativa e negativa, permitindo a demanda judicial de seu núcleo fundamental. A concessão do benefício assistencial, nestas hipóteses, justifica-se a partir do Princípio da Dignidade da Pessoa Humana, o qual possui, como núcleo essencial, plenamente sindicável, o mínimo existencial, isto é, o fornecimento de recursos elementares para a sobrevivência digna do ser humano.

Desde logo, torna-se imprescindível que os operadores do Direito que trabalham na área da seguridade social, de modo que o trabalho profissional neste 
domínio do conhecimento torne-se cada vez mais humana e adequado aos princípios constitucionais, em particular, ao princípio da dignidade a personalidade humana e o princípio do não retrocesso social.

A par disso, como detidamente mencionado acima, o critério de miserabilidade é questionado de maneira recorrente, principalmente no que diz respeito à inflexibilidade do artigo $20, \S 3^{\circ}$ da Lei Orgânica de Assistência Social, o qual estabelece como critério de enquadramento na situação de miserabilidade a renda per capita familiar inferior a $1 / 4$ do salário mínimo vigente.

Ocorre que, em muitos casos, cidadãos são impedidos de obter esse benefício pelo simples fato de o órgão responsável por concedê-lo, o INSS, não os considerar em situação de miserabilidade, analisando taxativamente o critério estabelecido pelo artigo, não realizando a averiguação específica de cada caso.

Conforme a Constituição Federal, é assegurada em diversos momentos a garantia do mínimo existencial, sendo elas o artigo 1으. III, o qual constitui como fundamento da República Federativa do Brasil a dignidade da pessoa humana, assim como o artigo $3^{\circ}$, III, quando estabelece como objetivo a erradicação da pobreza e da marginalização e redução das desigualdades sociais, e, por fim, em seu artigo 6을 quando detalha os direitos sociais dos indivíduos, destacando a passagem que menciona como direito social a assistência aos desamparados (BRASIL, 1988).

No momento quando o legislador estabeleceu o critério que ele adotou para estabelecer individualmente a situação de miserabilidade seria 1/4 do salário mínimo, restringiu-se um grande número de pessoas que necessitam de amparo, principalmente as que, por uma quantia irrisória, ultrapassam o requisito taxado.

Inúmeros são casos de cidadãos em estado de hipossuficiência que comparecem ao Instituto Nacional de Seguro Social requerendo o benefício de prestação continuada, sendo, no entanto, notificadas do seu não enquadramento no critério estrito estabelecido pela lei.

Desse modo, adiante, será analisado mais especificadamente outros critérios de miserabilidade conferida em outras leis, mas utilizados para a concessão do benefício de prestação continuada. 


\subsection{OUTROS CRITÉRIOS DE MISERABILIDADE PARA AFERIÇÃO DO BENEFÍCIO DE PRESTAÇÃO CONTINUADA}

Este item tem como finalidade apresentar outros critérios de miserabilidade das leis de Assistência Social no país, além daquele estabelecido pela LOAS, para demonstrar que houve mudanças de interpretação do legislador sobre o que se deve entender por pessoa necessitada, indicada no artigo 203, da Constituição Federal.

Como já expressado anteriormente, o critério de miserabilidade estabelecido na Lei n. 8.742/93 encontrasse no artigo 20 , parágrafo $3^{\circ}$. Considera-se incapaz de prover a manutenção da pessoa com deficiência ou idosa a família cuja renda mensal per capita seja inferior a 1/4 (um quarto) do salário mínimo.

É importante ressaltar, que após a entrada em vigor do LAOS, a economia brasileira passou por várias mudanças, combinadas com transformações fáticas, políticas, sociais e jurídicas, levando a uma mudança nos critérios para a concessão de benefícios, que cobrem todo o território da assistência social.

Com o advento de novas leis, especialmente na área da assistência social, o legislador continuou a dar uma nova interpretação ao termo necessitados, criando mais parâmetros para medir a condição de miséria de uma pessoa. Atualmente os programas de assistência social no Brasil utilizam o valor de meio salário mínimo como um indicador econômico para medir a exigência miséria.

Um exemplo é o contido no artigo $2^{\circ}$, parágrafo $2^{\circ}$, da Lei n. 10.689, de 13 de junho de 2003, que criou o Programa Nacional de Acesso à Alimentação - PNAA, consta que: "Os benefícios do PNAA serão concedidos, na forma desta Lei, para unidade familiar com renda mensal per capita inferior a meio salário mínimo" (BRASIL, 2003), ou seja, o critério de aferição de miséria de uma pessoa é considerado a renda inferior a meio salário mínimo, diferente do critério usado pelo LOAS.

Corroborando com o estudo posto, cabe transcrever parte da decisão do Ministro do Supremo Tribunal Federal, Gilmar Mendes, na Reclamação 4374 LOAS, julgando-a improcedente e declarando a inconstitucionalidade do parágrafo $3^{\circ}$, artigo 20, da LOAS, de forma incidental (BRASIL, 2013), grifo nosso:

Nesse contexto de significativas mudanças econômico-sociais, as legislações em matéria de benefícios previdenciários e assistenciais trouxeram critérios econômicos mais generosos, aumentando para $1 / 2$ 
do salário mínimo o valor padrão da renda familiar per capita. Por exemplo, citem-se os seguintes. O Programa Nacional de Acesso à Alimentação - Cartão Alimentação foi criado por meio da Medida Provisória n. - 108, de 27 de fevereiro de 2003, convertida posteriormente na Lei $n .-10.689$, de 13 de junho de 2003. A regulamentação se deu por meio do Decreto $n .-9.675$, de 16 de abril de 2003. O Programa Bolsa Família - PBF foi criado por meio da Medida Provisória n.- 132, de 20 de outubro de 2003, convertida na Lei $n .-$ 10.836, de 9 de janeiro de 2004. Sua regulamentação ocorreu em 17 de setembro de 2004, por meio do Decreto $n .-5.209$. Com a criação do Bolsa Família, outros programas e ações de transferência de renda do Governo Federal foram unificados: Programa Nacional de Renda Mínima Vinculado à Educação - Bolsa Escola (Lei 10.219/2001); Programa Nacional de Acesso à Alimentação - PNAA (Lei 10.689 de 2003); Programa Nacional de Renda Mínima Vinculado à Saúde - Bolsa Alimentação (MP 2.206-1/2001) Programa Auxílio-Gás (Decreto n.ำ 4.102/2002); Cadastramento Único do Governo Federal (Decreto 3.811/2001). Portanto, os programas de assistência social no Brasil utilizam, atualmente, 0 valor de $1 / 2$ salário mínimo como referencial econômico para a concessão dos respectivos benefícios. Tal fato representa, em primeiro lugar, um indicador bastante razoável de que o critério de $1 / 4$ do salário mínimo utilizado pela LOAS está completamente defasado e mostra-se atualmente inadequado para aferir a miserabilidade das famílias que, de acordo com o art. 203, V, da Constituição, possuem o direito ao benefício assistencial. Em segundo lugar, constitui um fato revelador de que o próprio legislador vem reinterpretando o art. 203 da Constituição da República segundo parâmetros econômico-sociais distintos daqueles que serviram de base para a edição da LOAS no início da década de $1990[\ldots]$.

Então, como observado, várias outras leis assistenciais, elaboradas pelo legislador pátrio, estabeleceram limites para a aferição da condição de necessitado diferentes daqueles utilizados pela Lei n. 8.742/93. Embora a redação atual do dispositivo que trata do requisito de miserabilidade da LOAS seja dada pela Lei $\mathrm{n}$. 12.435/11, não houve nenhum tipo de alteração desse critério em comparação ao que estabelecia na redação original na década de 90 . A única alteração realizada pela Lei n. 12.435/11, no que se refere ao dispositivo tratado, foi em relação ao termo pessoa portadora de deficiência, na qual passou-se a utilizar o termo pessoa com deficiência (BRASIL, 2011).

Em suma, esse valor de $1 / 4$ (um quarto) do salário mínimo é o parâmetro da LOAS desde 1993. Portanto, essas outras leis que foram comentadas são mais recentes, e devem ser levadas em consideração, ou seja, utilizadas como parâmetros no momento da aferição do requisito da miserabilidade para a concessão do benefício de prestação continuada da LOAS. Assim, em linhas abaixo, será aduzido algumas implicações decorrentes da grande divergência no entendimento da Administração Pública e o Poder Judiciário acerca do critério de miserabilidade da LOAS. 


\subsection{IMPLICAÇÕES DECORRENTES DA DIVERGÊNCIA DE ENTENDIMENTO DA ADMINISTRAÇÃO PÚBLICA E O PODER JUDICIÁRIO}

O critério objetivo considerando a renda familiar per capita máxima inferior a 1/4 do salário mínimo, instituído pela Lei no 8.742/1993, artigo 20, § 3o, a qual veio a regulamentar o artigo 203, inciso V, da Constituição Federal que até então tinha eficácia limitada ${ }^{4}$, surgiu no intuito de proporcionar eficácia plena ${ }^{5}$ para o referido dispositivo.

O requisito financeiro estipulado pela lei passou a gerar dúvida quanto à sua constitucionalidade, tendo em vista que, na prática, situações de patente miserabilidade social estavam ficando fora da cobertura do benefício assistencial previsto na Constituição Federal de 1988 (MENDES; BRANCO, 2014).

Segundo Ibrahim (2016, p. 14):

[...] ainda que o legislador frequentemente utilize-se de parâmetros objetivos para a fixação de direitos, a restrição financeira pode e deve ser ponderada com características do caso concreto, sob pena de condenar-se à morte 0 necessitado. Ainda que a extensão do benefício somente possa ser feita por lei, não deve o intérprete omitir-se à realidade social.

$\mathrm{Na}$ atualidade, existe uma controvérsia de entendimento entre a Administração Pública, que é representada pelo Instituto Nacional do Seguro Social INSS e pelo Judiciário, acerca do requisito de miserabilidade referido no parágrafo 3º, do artigo 20 da Lei Orgânica da Assistência Social (LOPES, 2014). O problema é se deve ou não ser concedido o relaxamento desse critério em favor das pessoas com deficiência ou para os idosos, considerando que a renda a renda per capita é calculada, e o valor excede $1 \frac{1}{4}$ (um quarto) do salário mínimo.

Como resultado deste debate, cada vez mais frequente essa questão nos tribunais do país (LOPES, 2014). Esta situação coloca sérios problemas para a

\footnotetext{
${ }^{4}$ Norma de eficácia limitada: "são aquelas que apresentam aplicabilidade indireta, mediata e reduzida, porque somente incidem totalmente sobre esses interesses, após uma normatividade ulterior que lhes desenvolva a aplicabilidade (por exemplo: CF, art. 37, VII: o direito de greve será exercido nos termos e nos limites definidos em lei específica)". (MORAIS, 2016, p. 65).

${ }^{5}$ São normas de eficácia plena "aquelas que, desde a entrada em vigor da Constituição, produzem, ou têm possibilidade de produzir, todos os efeitos essenciais, relativamente aos interesses, comportamentos e situações, que o legislador constituinte, direta e normativamente, quis regular" (por exemplo: os "remédios constitucionais)". (MORAIS, 2016, p. 65).
} 
sociedade, uma vez que, como afirmado anteriormente neste estudo, o número de pessoas com deficiência ou pessoas idosas, inquestionavelmente, em condições de pobreza, tem seu requerimento de concessão do BPC indeferido, uma vez que a renda familiar per capita é maior do que o determinado pela Lei n. 8.742/93.

Em decorrência disso, ocorreram vários questionamentos acerca do assunto, fato que culminou no ajuizamento, no Supremo Tribunal Federal, da Ação Direta de Inconstitucionalidade de ํㅜ 1.232/DF, tendo por finalidade a análise do $\S 3^{\circ}$, do artigo 20, da LOAS, no que se referia ao critério de miserabilidade.

A tese sustentada pelo Ministério Público Federal era de que $\circ \S 3^{\circ}$, do art. 20, da LOAS firmava a prescindibilidade da comprovação de necessidade assistencial para os casos de renda familiar per capita inferior a $1 / 4$ de salário mínimo, no entanto, isso não excluía a possibilidade de, na prática, em casos reais, comprovar-se que o idoso ou pessoa com deficiência não dispunha de meios para prover a própria subsistência ou de tê-la provida por sua família.

De outro norte, em processos judiciais, o requisito é constatado por perícia social, através de um relatório socioeconômico, realizado em visita domiciliar ou em outras instituições. Neste caso, há perguntas a serem preenchidas com dados do usuário, como: idade, escolaridade, coexistência familiar, relação de compartilhamento de custos com manutenção e tratamento médico, se está usando uma rede de governo; e indicações de pessoas que vivem na mesma residência, com conhecimento de idade, grau de parentesco, educação e renda, bem como outros casos individuais adequadamente analisados. Todo esse trâmite é previamente marcado, por juiz no momento da ação judicial (LOPES, 2014).

Em contrapartida, na via administrativa, a condição de miserabilidade é auferida através de documentos, sejam eles, testemunhais ou adquiridos ao longo da vida. No momento de requerer administrativamente o seu benefício assistencial junto ao INSS, o indivíduo preenche todos os dados referentes à sua vida privada, em documento denominado declaração sobre a composição do grupo e renda familiar do idoso ou portador de deficiência, quais sejam: número de pessoas que moram com o requerente, seu rendimento mensal, comprovação de renda, situação ocupacional, entre outros (BRASIL, 2017).

Devido à complexidade da avaliação, na esfera administrativa e judicial, o critério 1/4 (um quarto) do salário mínimo como sinal de miserabilidade é considerado 
um parâmetro para a medição da necessidade. Isso é norte para todos os pedidos, e na sede judicial aplica o princípio do livre julgamento do juiz ${ }^{6}$.

Insta salientar, como já explanado anteriormente, que a referida decisão do STF na ADI 1.232 foi proferida em 1998 e por essa época começaram a ser editadas normas legais contendo critérios mais abrangentes de concessão de outros benefícios assistenciais como, por exemplo, a Lei o 10.219/2001 (Bolsa Escola), a Lei no 10.689/2003 (Programa Nacional de Acesso à Alimentação) e a Lei no 10.836/2004 (Bolsa Família).

Portanto, o presente tópico tem a finalidade de identificar os pontos controversos entre a Administração Pública, representada pelo Instituto Nacional do Seguro Social - INSS, como já mencionado, e o Poder Judiciário no que se refere ao benefício de prestação continuada estabelecida no LOAS.

No caso do INSS, o requisito de renda familiar mensal per capita inferior a $1 / 4$ (um quarto) do salário mínimo é o único critério a ser levado em consideração para avaliar o estado de necessidade de uma pessoa que deseja o benefício de prestação continuada.

Em ataque acerca da não flexibilização do INSS ao critério de miserabilidade, sinalizam Mendes e Branco (2014, p. 664):

\begin{abstract}
A aplicação dos referidos critérios encontrou sérios obstáculos na complexidade e na heterogeneidade dos casos concretos. Se, antes da edição da Lei n. 8742/93, o art. 203, V, da Constituição era despido de qualquer eficácia - o que a doutrina especializada costuma denominar norma constitucional de eficácia limitada -, o advento da legislação regulamentadora não foi suficiente para dotá-lo de plena eficácia. Questionamentos importantes foram suscitados logo no início da aplicação da lei. E, sem dúvida, o mais importante dizia respeito ao critério de mensuração da renda familiar per capita. $O$ requisito financeiro estabelecido pela lei começou a ter sua constitucionalidade contestada, pois, na prática, permitia que situações de patente miserabilidade social fossem consideradas fora do alcance do benefício assistencial previsto constitucionalmente.
\end{abstract}

\footnotetext{
6 "O juiz é soberano na análise das provas produzidas nos autos. Deve decidir de acordo com o seu convencimento. Cumpre ao magistrado dar as razões de seu convencimento. Decisão sem fundamentação é nula pleno jure (CF 93 IX). Não pode utilizar-se de fórmulas genéricas que nada dizem. Não basta que o juiz, ao decidir, afirme que defere ou indefere o pedido por falta de amparo legal; é preciso que diga qual o dispositivo de lei que veda a pretensão da parte ou interessado e porque é aplicável no caso concreto" (NERY JÚNIOR, 2004, p. 519).
} 
$\mathrm{Na}$ atual conjuntura em que se vive, confirmou-se que a concessão do BPC, tornou-se uma questão de sorte (LOPES, 2014). A divergência é tão alta que, nas situações de recusa do INSS, tendo em conta a decisão administrativa, ao desrespeitar os critérios de miserabilidade trazidos por lei, o requerente deve se referir ao judiciário, dependendo do juiz em que a demanda é distribuída e se o juiz é muito positivista (legalista) ou decide com base em princípios legais gerais, os idosos ou pessoas com deficiência terá seu pleito deferido ou não, causando séria incerteza jurídica. Por isso, é necessário saber se este critério pode ser flexibilizado (IBRAHIM, 2016).

Tal fato influenciou ainda mais os magistrados a se utilizarem de critérios menos enrijecidos para julgar a concessão do benefício assistencial. Dessa forma, juízes e tribunais passaram a utilizar o valor de 1/2 salário mínimo como parâmetro para aferição da renda familiar per capita, fato que resultou no âmbito do Tribunal Regional Federal 4a Região, na aprovação da Súmula nํ 6, em 16 de novembro de 2004, com o seguinte conteúdo (BRASIL, 2004):

O critério de verificação objetiva da miserabilidade correspondente a $1 \frac{1}{4}$ (um quarto) do salário mínimo, previsto no art. 20 , § $3^{\circ}$, da Lei ํo 8.742/93, restou modificado para $1 / 2$ (meio) salário mínimo, a teor do disposto no art. 5ㄴ, I, da Lei no 9.533/97, que autorizava o Poder Executivo a conceder apoio financeiro aos Municípios que instituíssem programas de garantia de renda mínima associados a ações socioeducativas, e art. $2^{\circ}$, $\S 2^{\circ}$, da Lei $n^{\circ}$ 10.689/2003, que instituiu o Programa Nacional de Acesso à Alimentação PNAA.

Como leciona Santos (2016, p. 128), na mesma linha seguiu o entendimento do Superior Tribunal de Justiça de que "o STF não retirou a possibilidade de aferição da necessidade por outros meios de prova".

O requisito trazido pela LOAS é considerado um critério objetivo para verificar o status de necessidade para os indivíduos. No entanto, este critério objetivo não deve ser o único que é levado em consideração, pois há critérios subjetivos a serem considerados na análise de um caso concreto. Precisa-se analisar e procurar todas as variáveis possíveis para alcançar assim a justiça social.

Vale transcrever neste momento, uma jurisprudência do Egrégio Tribunal Regional Federal da 4ํㅡㄹ Região sobre o critério de miserabilidade: 
FASE DE CUMPRIMENTO DE SENTENÇA. DIFERIMENTO. O benefício assistencial é devido à pessoa portadora de deficiência e ao idoso que comprovem não possuir meios de prover a própria manutenção ou de tê-la provida por sua família. Em relação ao pressuposto econômico, o art. 20, § 3ㅇ, da Lei $n=8.742 / 1993$ - LOAS estabelecia que seria considerada hipossuficiente a pessoa com deficiência ou idoso cuja família possuísse renda per capita inferior a $1 / 4$ do salário mínimo. Entretanto, - Supremo Tribunal Federal, ao analisar os recursos extraordinários 567.985 e 580.963 , ambos submetidos à repercussão geral, reconheceu a inconstitucionalidade do $\S 3^{\circ}$ do art. 20 da Lei $n^{\circ} 8.742 / 1993$, assim como do art. 34 da Lei 10.741/2003 - Estatuto do Idoso, permitindo que - requisito econômico, para fins de concessão do benefício assistencial, seja aferido caso a caso. Comprovado o preenchimento dos requisitos legais, é devida a concessão do benefício assistencial, desde a DER. Deliberação sobre índices de correção monetária e taxas de juros diferida para a fase de cumprimento de sentença, a iniciar-se com a observância dos critérios da Lei 11.960/2009, de modo a racionalizar o andamento do processo, permitindo-se a expedição de precatório pelo valor incontroverso, enquanto pendente, no Supremo Tribunal Federal, decisão sobre o tema com caráter geral e vinculante. Precedentes do STJ e do TRF da 4⿳亠丷a Região. (BRASIL, 2017a,grifos do autor).

Ademais, corroborando a mesma linha de entendimento, cabe transcrever uma jurisprudência do Colendo Tribunal Regional Federal da $2^{\circ}$ Região:

PREVIDENCIÁRIO. AMPARO SOCIAL. LEI № 8.742/93. PREENCHIMENTO DOS REQUISITOS LEGAIS. CUSTAS. TAXA JUDICIÁRIA. JUROS MORA. - Remessa necessária e apelo do INSS em face de sentença que julgou procedente o pedido autoral, condenando a Autarquia a implementar o Benefício de Amparo Social, no artigo 20 da Lei 8.742/93, no valor de um salário mínimo. - O Colendo Superior Tribunal de Justiça, em reiteradas vezes, decidiu pela possibilidade de utilização de outros critérios, que não a renda familiar per capita inferior a $1 / 4$ (um quarto) de salário mínimo, para aferir a necessidade de percepção do benefício assistencial. $O$ valor arbitrado pela lei é apenas um parâmetro objetivo não criando absoluta presunção em qualquer Sentido. - Restam caracterizados tanto o estado de miserabilidade quanto o impedimento de longo prazo de natureza física para que a autora mantenha sua própria subsistência, nos termos do art. 20 , §§ $2^{\circ}$ e $3^{\circ}$, da Lei $8742 / 93$. - Os juros e a correção monetária das parcelas devidas, estes devem obedecer ao determinado pela Lei oㅜ 11.960/09. - O INSS é isento do pagamento de custas e taxa judiciária, nas ações em que for interessado na condição de autor, réu, assistente ou opoente, inclusive nas ações de natureza trabalhista, acidentária e de benefícios. (BRASIL, 2017b, grifos do autor)

O Egrégio Tribunal Regional Federal da 1ำ Região também apresenta uma jurisprudência sobre do critério de miserabilidade. É o que se vê em linhas abaixo:

ASSISTENCIAL. PROCESSUAL CIVIL. BENEFÍCIO DE AMPARO SOCIAL À PESSOA PORTADORA DE DEFICIÊNCIA. LEI № 8.742. REQUISITOS LEGAIS ATENDIDOS. RECONHECIMENTO. TERMO INICIAL. CORREÇÃO. JUROS. HONORÁRIOS. CUSTAS. 1. O benefício de prestação continuada é devido à pessoa com deficiência e ao idoso com 65 
anos ou mais, que comprovem não possuir meios de prover a própria manutenção nem de tê-la provida por sua família. 2. A família com renda mensal per capita inferior a $1 / 4$ do salário mínimo não é capaz de prover de forma digna a manutenção do membro idoso ou portador de deficiência física (§ $3^{\circ}$ art. 20, Lei 8.742/93). Contudo, o legislador não excluiu outras formas de verificação da condição de miserabilidade. Precedentes do STJ, da TNU e desta Corte. 3. Aplica-se o parágrafo único do artigo 34 do Estatuto do Idoso (Lei n. 10.741/03), por analogia, a pedido de benefício assistencial feito por pessoa com deficiência a fim de que benefício previdenciário recebido por idoso, no valor de um salário mínimo, não seja computado no cálculo da renda per capita prevista no artigo 20, § 3o, da Lei n. 8.742/93. (REsp 1355052, submetido à sistemática do $\S 7^{\circ}$ do art. 543-C do Código de Processo). 4. O Plenário do Supremo Tribunal Federal no julgamento da Reclamação no 4374/PE sinalizou compreensão no sentido de que o critério de renda per capita de $1 / 4$ do salário mínimo não é mais aplicável, motivo pelo qual a miserabilidade deverá ser aferida pela análise das circunstâncias concretas do caso analisado. 5. O laudo social (92/94) demonstrou que a autora, menor de idade, reside com seus genitores. A renda auferida pela família era de aproximadamente $R \$ 500,00$. Vulnerabilidade social constatada. 6. A perícia realizada $(102 / 106)$ consignou que a parte autora é portadora de fibrose cística, doença de caráter progressivo. Afirma o perito que a autora necessita de cuidados constantes dos familiares devido as manifestações clínicas da doença, o que demonstra a redução de capacidade laboral do grupo familiar. 7. DIB: requerimento administrativo, respeitada a prescrição quinquenal. Atrasados: correção monetária e juros moratórios conforme Manual de Orientação de Procedimentos para os Cálculos na Justiça Federal. 8. Horários de advogado: $10 \%$ sobre o valor da condenação, correspondente às parcelas vencidas até o momento da prolação do acórdão; Custas: isento. 9. Implantação imediata do benefício, nos termos do art. 497 do NCPC obrigação de fazer. 10. Apelação a que se dá provimento, nos termos dos itens 7 e 8. (BRASIL, 2016, grifos do autor).

O Superior Tribunal de Justiça não diverge da asserção adotada neste trabalho:

PREVIDENCIÁRIO E PROCESSUAL CIVIL. AGRAVO REGIMENTAL EM AGRAVO EM RECURSO ESPECIAL. BENEFÍCIOASSISTENCIAL. POSSIBILIDADE DE DEMONSTRAÇÃO DA CONDIÇÃO DE MISERABILIDADE DO BENEFICIÁRIO POR OUTROS MEIOS DE PROVA, QUANDO A RENDA PER CAPITA DO NÚCLEO FAMILIAR FOR SUPERIORA 1/4 DO SALÁRIO MÍNIMO. RESP 1.112.557/MG, REPRESENTATIVO DA CONTROVÉRSIA. EXCLUSÃO DO BENEFÍCIO PREVIDENCIÁRIO NO VALOR DE UM SALÁRIO MÍNIMO RECEBIDO POR IDOSO QUE FAÇA PARTE DO NÚCLEO FAMILIAR. APLICAÇÃO, POR ANALOGIA, DO ART. 34, PARÁG. ÚNICO, DA LEI 10.741/2003 (ESTATUTO DO IDOSO). ENTENDIMENTO CONSOLIDADO NO JULGAMENTO DO RESP 1.355.052/SP, JULGADO SOB O RITO DO ART. 543-C DO CPC/1973. AGRAVO REGIMENTAL DO INSS A QUE SE NEGA PROVIMENTO. 1. Esta Corte, no julgamento do REsp. 1.112.557/MG, representativo decontrovérsia, DJe 20.11.2009, pacificou o entendimento de que a limitação do valor da renda per capita familiar não deve ser considerada a única forma de se comprovar que a pessoa não possui outros meios para prover a própria manutenção ou de tê-la provida por sua família, pois é apenas um elemento objetivo para se aferir a necessidade, ou seja, presume-se 
absolutamente a miserabilidade quando comprovada a renda per capita inferior a 1/4 do salário mínimo. 2. Do mesmo modo, firmou-se a orientação, na análise do REsp. 1.355.052/SP, julgado sob o rito do art. 543-C do CPC, de que o art. 34,parág. único da Lei 10.741/2003 deve ser interpretado analogicamente, de modo que outros benefícios já concedidos a outro membro da família possam ser excluídos do cálculo da renda familiar para fins de concessão de benefício assistencial. 3. Agravo Regimental do INSS a que se nega provimento. (BRASIL, 2017c, grifos do autor)

Conforme entendimento do Superior Tribunal de Justiça - STJ, o rendimento familiar de renda per capita inferior a 1/4 (um quarto) do salário mínimo será a hipótese absoluta de miserabilidade, dispensando a emissão de outros meios de prova. No entanto, para além dos limites estabelecidos, podem ser utilizados outros meios de prova que indicam o estado de necessidade, expresso no estado da falta absoluta de meios de subsistência.

Em outras palavras, o STJ entende que a condição de miserabilidade desencadeada pelo LOAS não é um critério absoluto, porque deve ser considerado como um limite mínimo, o quantum considerado objetivamente insuficiente para suportar à subsistência de uma pessoa com deficiência ou idosos, o que não impede o julgador de usar outros fatores que tenham uma condição para provar o estado de necessidade do requerente do benefício.

Os critérios subjetivos são importantes para a aferição no caso específico de cumprimento do requisito da miserabilidade. Deve-se mesclar baseado nos princípios da razoabilidade e da proporcionalidade, o critério objetivo trazido pela lei com o subjetivo, que dependerá de cada caso particular.

Destarte, os idosos e pessoas com deficiência necessitados continuam a testemunhar $\mathrm{o}$ indeferimento de seus benefícios assistenciais em virtude de um critério objetivo legal de concessão defasado e injusto. E, consequentemente, precisam manejar ações judiciais para aguardar durante longos e sofridos anos o trânsito em julgado de uma sentença na busca da retração de sua miséria e do aumento de sua dignidade, e infelizmente na incerteza se ela lhe será favorável.

Além disso, como já dito no item anterior, em decisão do Supremo Tribunal Federal - STF, na Reclamação 4374, o Ministro Relator Gilmar Mendes julgou-a improcedente, declarando a inconstitucionalidade do parágrafo $3^{\circ}$, artigo 20 , da LOAS, sob o argumento de que ao longo dos últimos anos houve uma proliferação de leis que estabeleceram critérios mais elásticos para a concessão de outros benefícios assistenciais. Afirmou ainda, na decisão que o contexto da economia 
brasileira também mudou, o que justamente favoreceu essa criação de critérios mais generosos para aferição da miserabilidade (BRASIL, 2013).

Vale ressaltar que, a decisão proferida pelo STF, declarando a inconstitucionalidade do critério de miserabilidade estabelecido pela LOAS, foi realizada de forma incidental, sem determinar, entretanto, a nulidade de tal dispositivo.

Essa inconstitucionalidade progressiva do artigo 20, parágrafo $3^{\circ}$ do LOAS, fez com que vários magistrados estabelecessem o valor de metade do salário mínimo como requisito para aferição da condição de miserabilidade do indivíduo, pois, é o estabelecido atualmente pelos programas de assistência social no Brasil, como referencial econômico para a concessão de benefícios, como foi acima descrito (LOPES, 2014).

Reforçando o entendimento aqui defendido, cabe transcrever trecho da decisão do Ministro Gilmar Mendes, da Reclamação 4374 (BRASIL, 2013):

\begin{abstract}
Nesse meio tempo, observou-se certa proliferação de leis que estabeleceram critérios mais elásticos para a concessão de outros benefícios assistenciais, tais como: a Lei 10.836/2004, que criou o Bolsa Família; a Lei 10.689/2003, que instituiu o Programa Nacional de Acesso à Alimentação; a Lei 10.219/01, que criou o Bolsa Escola; a Lei 9.533/97, que autoriza o Poder Executivo a conceder apoio financeiro a Municípios que instituírem programas de garantia de renda mínima associados a ações socioeducativas; e o Estatuto do Idoso (Lei 10.741/03). Isso foi visto pelos aplicadores da LOAS como um fato revelador de que o próprio legislador estaria reinterpretando o art. 203 da Constituição da República. Abria-se, com isso, mais uma porta para a concessão do benefício assistencial fora dos parâmetros objetivos fixados pelo art. 20 da LOAS. Juízes e tribunais passaram a estabelecer o valor de $1 / 2$ salário mínimo como referência para a aferição da renda familiar per capita [...].
\end{abstract}

Portanto, como pode ser visto neste tópico, há uma diferença na interpretação entre a Administração Pública e o Judiciário acerca do requisito de miserabilidade do LOAS. Este critério, que utiliza o valor de 1/4 (um quarto) do salário mínimo como parâmetro para aferir as necessidades de um indivíduo já foi considerado inconstitucional, bem como, diante da análise do presente trabalho observa que esse critério não abarca a grande diversidade de casos, haja vista que um critério meramente numérico não pode ser utilizado para procedência ou improcedência de um benefício que garante o sustento do requerente, a sua dignidade e o seu mínimo existencial. Portanto, sua flexibilidade deve ser em situações que sejam claramente visíveis pela necessidade ou pobreza extrema de uma pessoa com deficiência ou 
idosos, o que, no entanto, no cálculo da renda familiar per capita dessa pessoa, é superior a $1 \frac{1}{4}$ (um quarto) do salário mínimo (ABREU, 2015).

Como já explanado anteriormente, a grande divergência entre a Administração Pública e o Poder Judiciário no que se refere à concessão do BPC, decorre em razão da não flexibilização da Lei n. 8.742/93 por parte do INSS, em relação ao critério de miserabilidade.

O critério para avaliar o status de necessidade do indivíduo, iniciado pelo LOAS, sofreu um processo de inconstitucionalidade nos últimos anos desde a sua proclamação, e atualmente, está confirmado seu desacordo com a Constituição Federal, violando os princípios da dignidade humana, da solidariedade social, da justiça social, entre outros. O Estado deve fornecer o mínimo existencial do indivíduo necessitado, e esta medida não deve ser anexada a um único critério objetivo e um critério desatualizado que não corresponde à nossa realidade fática e social (ABREU, 2015).

Leitão e Meirinho (2013), posicionam-se que este é um critério objetivo e único, por se tratar de uma simples operação numérica na qual a renda de todo o grupo familiar é somada e dividida pela quantidade de integrantes.

Vale salientar que o INSS deve estrita observância ao princípio da legalidade, consoante artigo 37 da Constituição Federal de 1988, não sendo possível relativizar a aludida norma legal para beneficiários cuja renda per capita ultrapasse o limite descrito no referido dispositivo legal, ainda que se façam presentes circunstâncias peculiares que possam conduzir a alguma situação de pobreza (TAKAMORI, 2014).

Essas discussões acarretaram no aumento das concessões judiciais do benefício de prestação continuada da LOAS, o que sobrecarrega o Poder Judiciário, dificultando a prestação jurisdicional célere.

Este fato, que pode ser chamado de judicialização excessiva da Seguridade Social, deveu-se à falta de eficácia dos direitos constitucionalmente garantidos e à inconsistência das políticas legislativas implementadas no país que estabelecem diferentes parâmetros para a mesma contingência social, o que prejudica completamente a sociedade em geral (LOPES, 2014).

Há uma situação de injustiça social em relação a pessoas com deficiência e aos idosos que precisam de ajuda para não viver de forma desumana. Deveseinterpretar as leis de acordo com os regulamentos estabelecidos na Constituição Federal, sempre com o objetivo de unidade constitucional, a fim de alcançar a 
máxima eficiência do seguro social, o que resultou na inclusão social dos menos favorecidos (TAKAMORI, 2014).

Como já foi explicado no tópico anterior, poderia ser usado a interpretação que mescla o critério objetivo de LOAS com requisitos subjetivos, que dependerá da análise do caso concreto, bem como a interpretação que considera como um parâmetro para medir o critério da miserabilidade o valor de metade do salário mínimo.

Vale a pena transcrever, um trecho da Reclamação 4374 de relatoria do Ministro Gilmar Mendes, onde o ministro pondera a preocupação com o sistema financeiro e orçamentário da assistência social:

É certo que não cabe ao Supremo Tribunal Federal avaliar a conveniência política e econômica de valores que podem ou devem servir de base para a aferição de pobreza. Tais valores devem ser o resultado de complexas equações econômico-financeiras que levem em conta, sobretudo, seus reflexos orçamentários e macroeconômico e que, por isso, devem ficar a cargo dos setores competentes dos Poderes Executivo e Legislativo na implementação das políticas de assistencialismo definidas na Constituição. No processo de reflexão e construção da presente decisão, realizei diversas reuniões com as autoridades competentes do Ministério do Desenvolvimento Social (Secretaria Nacional de Assistência Social, Departamento de Benefícios Assistenciais), do Instituto Nacional do Seguro Social e da Advocacia-Geral da União (inclusive a Procuradoria-Geral Federal). Há uma constante preocupação com o impacto orçamentário de uma eventual elevação do atual critério de $1 / 4$ do salário mínimo para $1 / 2$ salário mínimo. Estudos realizados pelo IPEA e pelo MDS, em janeiro de 2010, demonstram que, se viesse a vigorar o critério de renda per capita no valor de $1 / 2$ salário mínimo, os recursos necessários para investimento no BPC em 2010 chegariam a R\$ 46,39 bilhões, ou seja, $129,72 \%$ a mais do que a projeção do ano (R\$20,06 bilhões). [...] De fato, a análise sobre a adequação do critério de $1 / 4$ do salário mínimo não pode desconsiderar 0 fato de que, num quadro de crescente desenvolvimento econômico e social, também houve um vertiginoso crescimento da quantidade de benefícios assistenciais concedidos pelo Estado brasileiro. De aproximadamente $\mathbf{5 0 0 . 0 0 0}$ (quinhentos mil) benefícios concedidos em 1996, a quantidade de idosos e deficientes beneficiários passou para atuais 3.644.591 (três milhões, seiscentos e quarenta e quatro mil, quinhentos e noventa e um) (Fonte: Ministério do Desenvolvimento Social e Combate à Fome - MDS). Em média, é gasto mensalmente 2 (dois) milhões de reais com esse benefício. Em valores acumulados até o último mês de abril de 2012, o custo total desses benefícios neste ano foi de 8.997.587.360 (oito bilhões, novecentos e noventa e sete milhões, quinhentos e oitenta e sete mil, trezentos e sessenta). Assim, tudo indica que, até o final deste ano de 2012, o custo anual do benefício assistencial será superior a 24 bilhões de reais. [...] Em todo caso, o legislador deve tratar a matéria de forma sistemática. Isso significa dizer que todos os benefícios da seguridade social (assistenciais e previdenciários) devem compor um sistema consistente e coerente.Com isso, podem-se evitar incongruências na concessão de benefícios, cuja consequência mais óbvia é o tratamento anti-isonômico entre os diversos beneficiários das políticas governamentais de assistência social [...]. (BRASIL, 2013, grifo do autor) 
Como é perceptível, há uma grande preocupação devido ao impacto negativo sobre o orçamento da Seguridade Social, causando por mudanças na interpretação do critério de miserabilidade trazido pelo LOAS.

A alteração do texto de lei que altera o requisito da miserabilidade da LOAS deve ser realizada, mesmo com o aumento dos custos do Estado com a Seguridade Social como resultado do aumento do número de concessões de benefícios assistenciais. Pois, utilizando-se do princípio interpretativo da harmonização, quando constatado um conflito de normas principiológicas, no caso sub examine, princípio do equilíbrio econômico e financeiro orçamentário e o princípio da dignidade da pessoa humana, deverá haver um sopesamento ou uma cedência recíproca dos princípios em colidência, baseando-se na razoabilidade e na proporcionalidade, para que se busque o resultado menos prejudicial para a sociedade. Busca-se uma maior luta pela justiça social. Portanto, o parâmetro do estado de necessidade precisa ser alterado estabelecendo um critério mais generoso (LOPES, 2014).

Portanto, restou plenamente demonstrado a divergência de entendimento da Administração Pública, representada pelo INSS e o Judiciário, onde em suma, o INSS usa unicamente o critério de $1 \frac{1}{4}$ (um quarto) do salário mínimo, como meio de não concessão do benefício assistencial, não o flexibilizando.

Em contrapartida o Judiciário tem uma visão mais humanística, analisando todo o contexto familiar para a aferição da miserabilidade do requerente, sendo ainda, que o judiciário tem entendido que o critério de miserabilidade deve ser de $1 / 2$ (meio) salário mínimo (IBRAHIM, 2016). Nessa linha, cabe mencionar abaixo mais especificadamente ao princípio da dignidade humana analisando sua (in) conformidade com o aluído princípio.

\subsection{A (IN) CONFORMIDADE COM O PRINCÍPIO CONSTITUCIONAL DA DIGNIDADE DA PESSOA HUMANA}

Como já exposto no capítulo anterior, injustiça seria não asseverar que o princípio da dignidade da pessoa humana é um dos alicerces da Constituição da República Federativa do Brasil de 1988, constituindo o mais importante dos fundamentos, pois, além de iluminar a interpretação das leis ordinárias, detém um conteúdo valorativo imensurável. 
Dotada de um valor supremo do Estado democrático de direito, a Constituição Federal estabelece a interpretação e aplicação de todos os direitos fundamentais, reconhecendo o direito de todo ser humano a ser respeitado como pessoa e a ser entendido como o centro e o fim do direito.

A dignidade da pessoa humana é inserta como fundamento do Estado Democrático de Direito, consagrada no art. $1^{\circ}$, inciso III, da Constituição Federal, in verbis(BRASIL, 1988):

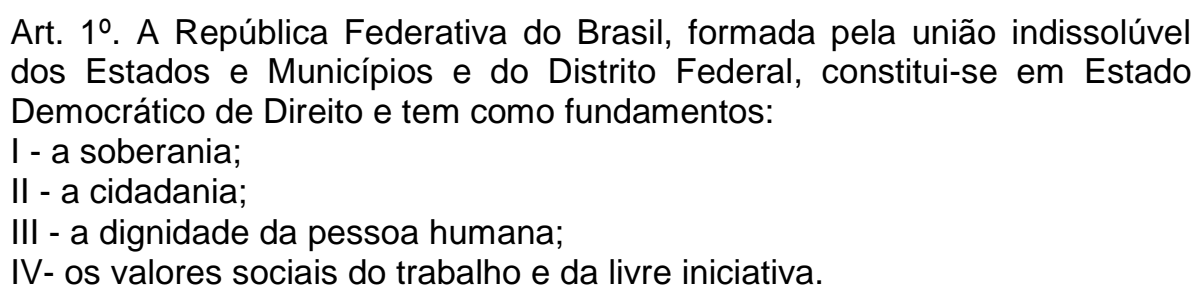

Sob a concepção majoritária, a tutela a dignidade da pessoa humana independe de circunstâncias alheias. Caracteriza-se como intangível, irrenunciável e inalienável, bastando a condição humana, inerente a própria espécie, para ser titular de direitos fundamentais reconhecidos pelo Estado, bem como pela sociedade (SARLET, 2012)

Flávia Piovesan (2006) afirma que todo ser humano tem uma dignidade inerente, incondicionada que independe de qualquer critério, senão apenas ser humano. Dessa forma, o princípio da dignidade da pessoa humana apresenta-se como uma norma direcionadora de um fim a ser alcançado, uma diretriz de atuação para o Estado, ditando os deveres para a promoção dos meios necessários a uma vida humana digna.

Acresça-se que a dignidade da pessoa humana como preceito ético e fundamento constitucional requer do Estado respeito, proteção e garantia de efetivação dos direitos dela decorrentes. Dessa forma, todo ser humano é sujeito de direitos e deveres e como tal deve ser tratado (PIOVESAN, 2006).

Sarlet (2012, p. 73) ensina que a dignidade da pessoa humana é:

A qualidade intrínseca e distintiva reconhecida em cada ser humano que o faz merecedor do mesmo respeito e consideração por parte do Estado e da comunidade, implicando, neste sentido, um complexo de direitos e deveres fundamentais que assegurem a pessoa tanto contra todo e qualquer ato de cunho degradante e desumano, como venham a lhe garantir as condições existências mínimas para uma vida saudável, além de propiciar e promover sua participação ativa e co-responsável nos destinos da própria existência e 
da vida em comunhão com os demais seres humanos, mediante o devido respeito aos demais seres que integram a rede da vida.

Desse modo, a abstenção do Estado não repousa apenas na proteção patrimonial dos indivíduos, porquanto, consubstancia no dever jurídico do Estado de promover políticas públicas positivas que garantam condições materiais mínimas para a existência digna do homem. A conduta comissiva estatal, portanto, proclamase como referência para a efetivação dos direitos fundamentais individuais e coletivos, sociais ou políticos, em tutela a dignidade da pessoa humana (MARTINS, 2016).

Percebe-se que a Lei Orgânica da Assistência Social, ao prever o critério objetivo de aferição de renda familiar no valor inferior a $1 / 4$ (um quarto) do salário mínimo mensal por pessoa, como exposto anteriormente, viola diretamente esse princípio, uma vez que a não observância do caso concreto, dos gastos reais de cada grupo familiar pode culminar em famílias em condições de patente miserabilidade excluídas da assistência social.

$O$ fato de possuir uma renda mensal por pessoa que ultrapasse o limite supramencionado não significa que a família disponha de uma confortável situação financeira, uma vez que ela pode necessitar arcar com despesas essenciais, em razão da deficiência ou idade avançada.

Vale ressaltar que, dependendo da situação do beneficiário, esses custos que pela legislação em vigor não são considerados, podem sujeitar a família ao desembolso de quantias desmoderadas que se deduzidas da renda total e calculada a renda per capita, implicam um valor bem inferior a $1 / 4$ de salário mínimo por indivíduo, estando abaixo do mínimo existencial vital que o Estado deve proporcionar, caracterizando o estado de penúria.

Quando se trata do mínimo existencial, estamos lidando com a questão que é basicamente sobre a realização dos direitos básicos, que aponta para a realização do princípio da dignidade humana. Embora seja o resultado da conquista histórica, o reconhecimento e a promoção da dignidade expressam a construção de razões, apontam um dever ser. Isso significa que não pode ser prejudicado e deve ser protegido e promovido (TAKAMORI, 2014).

Os direitos fundamentais, mormente os sociais contidos no artigo 6을 Magna de 1988, são, nessa situação, a manifestação do conteúdo da dignidade humana e a sua concretização efetiva nas instituições sociais. Destarte, a partir da 
dignidade, como fundamento constitucional, que se justifica e até mesmo se impõe o reconhecimento do direito ao mínimo existencial (IBRAHIM, 2016).

Os direitos sociais, portanto, são tratados como direitos fundamentais impondo-se, em última análise, respeito à dignidade da pessoa humana. Alexandre de Moraes (2016, p. 428) ressalta:

\begin{abstract}
Direitos Sociais são direitos fundamentais do homem, que se caracterizam como verdadeiras liberdades positivas, de observância obrigatória em um Estado Social de Direito tendo por finalidade a melhorias das condições de vida aos hipossuficientes, visando a concretização da igualdade social, e consagrados como fundamentos do Estado democrático, pelo art. 1ํ, IV, da Constituição Federal.
\end{abstract}

Acrescenta Novelino (2013) as características normativo-estruturais dos direitos sociais, as quais se subdividem em direitos de defesa (ou direitos de resistência) ou direito a prestações (ou direito prestacionais). Os primeiros preveem o dever de abstenção aos limites do poderio estatal, a fim de preservar as liberdades individuais do homem. Os segundos, em contrapartida, no dever de tutelar os bens jurídicos, sob o viés protecionista, bem como sob a esfera garantidora de sua fruição.

Embora haja visões mais ambiciosas do alcance do princípio da dignidade da pessoa humana, existe razoável consenso de que ele inclui pelo menos os direitos à renda mínima, saúde básica, educação fundamental e acesso à justiça. Infelizmente, até mesmo esses direitos mais básicos muitas vezes não são respeitados. Flávia Piovesan (2006, p. 26), destaca:

[...] as violações, as exclusões, as discriminações, as intolerâncias, são um construído histórico, a ser urgentemente desconstruído. Há que se assumir o risco de romper com a cultura da "naturalização" da desigualdade e da exclusão social, que, enquanto construídos históricos, não compõem de forma inexorável o destino de nossa humanidade. Há que se enfrentar essas amarras, mutiladoras do protagonismo, da cidadania, da dignidade e da potencialidade de seres humanos.

É triste que a ordem jurídica do país permaneça inalterada em relação a tantas injustiças sociais, como demonstrado pelas numerosas ações das pessoas humilhadas e pobres que estão lutando pelo BPC, após o indeferimento do benefício pelo INSS, porque as receitas excedem o limite legal, no entanto, 
independentemente de se levar em conta o real e elevado custo com produtos indispensáveis à manutenção da sua vida e saúde.

$\mathrm{Na}$ Reclamação 4374 de relatoria do ministro Gilmar Mendes, onde foi sinalizando pela inconstitucionalidade do aduzido critério de miserabilidade, pode-se confirmar a sua afronta ao princípio da dignidade da pessoa humana na redação do voto da ministra Carmen Lúcia (BRASIL, 2013, grifos do autor):

[...] Quer o INSS, ora Reclamante, se considere ser a definição do benefício concedido pela sentença reclamada incompatível com o quanto decidido na Ação Direta de Inconstitucionalidade 1.232. Não é o que se tem no caso. Também afirma que haveria incompatibilidade entre aquela decisão e a norma do $\S 3^{\circ}$ do art. 20 da Lei n. 8.742/93. Afirmo: e a miséria constatada pelo juiz é incompatível com a dignidade da pessoa humana, princípio garantido no art. 1ㅜ, inc. III, da Constituição da República; e a política definida a ignorar a miserabilidade de brasileiros é incompatível com os princípios postos no art. $3^{\circ}$ e seus incisos da Constituição; e a negativa do Poder Judiciário em reconhecer, no caso concreto, a situação comprovada e as alternativas que a Constituição oferece para não deixar morrer à míngua algum brasileiro é incompatível com a garantia da jurisdição, a todos assegurada como direito fundamental (art. 5, inc. XXXV, da Constituição da República).

De acordo com o voto acima, pode-se perceber que a dignidade da pessoa humana, o mínimo invulnerável que o estatuto jurídico deve assegurar e o valor que merecem as pessoas enquanto seres humanos não estão sendo respeitados no âmbito administrativo de concessão do benefício assistencial.

Nos moldes já expostos, no capítulo anterior, o benefício de prestação continuada retrata-se como ferramenta de iniciativa pública para memorizar às desigualdades sociais, bem como amparar os necessitados. Apresenta-se como a obrigação-dever do Estado de promover a existência digna do homem incapacitado de prover sua própria subsistência, nem tê-la satisfeita por sua família, nos termos da lei.

Diante do ostentado, verifica-se que utilizar exclusivamente o parâmetro objetivo de renda correspondente a $1 \frac{1}{4}$ (um quarto) do salário mínimo por cada pessoa do grupo familiar, previsto no $3^{\circ}$, do artigo 20 , da Lei n. 8.742/93, demonstra-se insuficiente para avaliar a miserabilidade do indivíduo, ofendendo categoricamente sua dignidade.

Posiciona-se Sarlet (2012, p. 162), a despeito da relativização dos direitos fundamentais, ofensa à dignidade como valor supremo, absoluto, insubstituível e inerente ao homem: 
[...] a doutrina majoritária se opõe veementemente a qualquer tipo de restrição à dignidade pessoal, de tal sorte que se chegou a afirmar que cada restrição à dignidade (ainda que fundada na preservação de direitos fundamentais ou proteção da dignidade de terceiros) importa em sua violação e, portanto, encontra-se vedada pelo ordenamento jurídico.

De modo a garantir a efetividade da dignidade da pessoa humana, bem como da finalidade da assistência social, qual seja, garantir o atendimento das necessidades básicas dos cidadãos. O melhor a se fazer é aferir a miserabilidade do sujeito ou do grupo familiar com base nos mais diversos elementos de prova: renda familiar per capita, laudo socioeconômico, depoimento testemunhal, etc.

Nesse raciocínio, é necessário destacar que deixar de conceder o benefício simplesmente pelo fato de a família atingir o limite legal ou superá-lo, é ferir em demasia o Princípio Constitucional da Dignidade da Pessoa Humana. Isso porque o indivíduo só é completo se tratado com dignidade, e estimulá-lo ao desemprego ou até mesmo ao trabalho informal, para cumprir exclusivamente os preceitos legais, excede qualquer limite do tolerável, vez que a miséria não deixa de existir em razão do não preenchimento do requisito legal com valores absolutos (ABREU, 2015).

In casu, sob a imposição da observância fundamental, a concessão do benefício de prestação continuada, em destaque, a aferição da renda per capita para fins concessórios, constrói-se sob o erige da dignidade da pessoa humana. Para Sergio Pinto Martins (2016, p. 72) "[...] implica em reconhecer que um dos fins do Estado brasileiro deve ser o de propiciar as condições materiais mínimas para que as pessoas tenham dignidade".

A decisão do Supremo Tribunal Federal, na ADI 1.232, não absteve à estrita aplicação do critério legal do benefício de prestação continuada pelo órgão judiciário, mas sim à luz da dignidade da pessoa humana e dos objetivos constitucionais, como fim mediato, a efetivação dos direitos fundamentais sociais. (BRASIL, 1998).

Nesse sentido, Sarlet (2012, p. 313) ensina que:

[...] o critério impugnado na ADin 1.232 seguiu sendo objeto de acirrada controvérsia, inclusive em sede jurisdicional, resultante em importantes decisões que, efetuando um leitura embasada no princípio da dignidade da pessoa humana, afastaram a limitação imposta pela Lei 8.742/93, entendendo que mesmo em sendo a renda per capita familiar superior ao salário mínimo, existe a possibilidade de comprovação da efetiva falta de meios de prover o próprio sustento e/ou de tê-lo provido pela família, em face de circunstâncias especiais no caso concreto. 
A dignidade da pessoa humana relaciona-se, ainda, com o princípio do bemestar social consagrado no art. 193 da Lei Fundamental. À promoção da dignidade, permite condições ao indivíduo, para que se possa desfrutar à vida com tranquilidade e segurança, sem afetação de eventuais contingências danosas (FERREIRA, 2007).

Sendo assim, o desrespeito à vida e a integridade física do homem, na ausência de condições mínimas para sua existência digna, seja na desigualdade latente em relação aos demais, igualmente considerados, ora pelo absolutismo do poderio estatal, nega-se a definição de dignidade, e numa posição contrária, passarse-á a ser objeto de arbítrio de injustiças (SARLET, 2012).

Conclui-se que à validade da norma condiciona-se ao seu status de justiça. Noberto Bobbio (2005, p.55), ensina que "[...] há princípios jurídicos fundamentais mais forte que a normatividade jurídica, que uma lei que os contrarie carece de validade". Complementa, "onde a justiça não é nem mesmo perseguida [...] é consciente negada em nome do direito positivo, a lei não somente é direito injusto como carece em geral de juridicidade" (BOBBIO, 2005, p. 55).

Portanto, diante do estudo realizado nesta pesquisa tem-se que o ideal para minimizar o problema real que o requisito da miserabilidade acarreta, seria a alteração da referida Lei Orgânica da Assistência Social - LOAS, contudo como este trabalho não tem este objetivo, tem-se que a análise do critério de miserabilidade da LOAS deve ser feito a par dos princípios constitucionais, buscando a aplicação da dignidade da pessoa humana, sendo este o princípio basilar na resposta do requerimento do benefício.

Destarte, que o julgador deve se reportar à Constituição, que pugna pela dignidade da pessoa humana, combate à pobreza e construção de uma sociedade livre, justa e solidária buscando no caso concreto a verificação efetiva e concreta da hipossuficiência do requerente do benefício de prestação continuada, contudo, a análise da concessão, deve se reportar ao princípio da dignidade da pessoa humana.

Com efeito, a relevância da dignidade da pessoa humana transcende a sua conceituação e o seu significado, seja sob a natureza fundamental do Estado Democrático de Direito, seja sob o viés axiológico do sistema constitucional. A pluralidade de definições remonta-se essencial para fins teóricos. Na prática, o que se espera é a garantia de um mínimo existencial aos indivíduos para que possam 
usufruir dos demais direitos fundamentais, estes como pressupostos basilares do real conceito de dignidade e os ditames de justiça. 


\section{CONSIDERAÇÕES}

A Assistência Social constitui um dos pilares da Seguridade Social, juntamente com a Saúde e a Previdência Social. Conforme os artigos 194, caput e 203, caput da Constituição Federal, tem-se a Seguridade Social como um conjunto integrado de ações de iniciativa dos Poderes Públicos e da sociedade, destinadas a assegurar os direitos relativos à Saúde, à Previdência e à Assistência Social, e que esta última será prestada a quem dela necessitar, independentemente de contribuição à Seguridade Social.

Nesse palmilhar, a Constituição Federal garante em seu texto constitucional vida digna a cidadãos; torna-se imprescindível analisar o contido na Constituição Federal em seu artigo 203, inciso V, regulamentado pela lei 8.742 de 1993, em seu artigo 20 da Lei Orgânica de Assistencial Social (LOAS), no qual firmou uma série de garantias de proteção aos direitos sociais, implicando assim, maior amparo aos direitos individuais. $O$ benefício de prestação continuada é previsto como garantia à pessoa portadora de deficiência e ao idoso com 65 anos ou mais, desde que comprovem não possuir meios de prover a própria manutenção ou tê-la provida por sua família, neste sentido indaga-se: 0 critério de 1/4 (um quarto) para aferição do benefício de prestação continuada da Lei Orgânica de Assistência Social (LOAS) atende à dignidade humana?

Dessa forma, levantou-se a hipótese, que o julgador deve se reportar à Constituição, que pugna pela dignidade da pessoa humana, combate à pobreza e construção de uma sociedade livre, justa e solidária buscando no caso concreto a verificação efetiva e concreta da hipossuficiência do requerente do benefício de prestação continuada. $O$ julgador deve estar ciente que a análise dos pressupostos da concessão do benefício assistencial envolve uma reflexão que vai além dos limites objetivos absolutos que a Lei no $8.742 / 1993$ e seus decretos regulamentadores originariamente pretenderam estabelecer. Isto porque o exame da necessidade da concessão da prestação assistencial abarca diversas questões fáticas, que devem ser avaliadas caso a caso. Com efeito, os critérios legais podem ser flexibilizados dependendo das condições pessoais do postulante ao benefício. A análise da concessão, deve se reportar ao princípio da dignidade da pessoa humana. 
Para granjear o objetivo dessa pesquisa, no que afeta ao aspecto metodológico, utilizou-se o método hipotético-dedutivo e foi utilizada a técnica de pesquisa bibliográfica e documental, tais como; a doutrina e legislação. Outrossim, a análise da legislação pertinente ao tema, principalmente a Lei n. 8.742/93 e a Constituição da República Federativa do Brasil foi indispensável para que a pesquisa fosse desenvolvida.

Com o designo de efetivar os objetivos resignados no projeto de pesquisa, o trabalho foi fragmentado em três capítulos.

No primeiro capítulo foi estudada a assistência social que é um dos pilares da seguridade social, abordando seu desenvolvimento histórico, bem como a própria seguridade social e o seu contexto histórico. Assim, constatou-se que a assistência social é pautada na proteção familiar, sendo que, no Brasil, a Constituição Federal de 1988, tratou da assistência social nos artigos 203 e 204.

Posteriormente, analisou-se o conceito de assistência social, o qual foi esculpido no artigo 203 da Constituição da República Federativa do Brasil, sendo posteriormente regulamentado pela Lei Orgânica da Assistência Social a qual definiu no artigo $1^{\circ}$ o conceito de assistência social.

Nesse passo, foi examinado os princípios da assistência social, os quais estão submetidos aos princípios constitucionais. Porém, os artigos 203 e 204, da Constituição Federal e o artigo 4ํㅡㄹ da Lei Orgânica de Assistência Social, têm regras específicas que devem orientar as políticas públicas destinadas à cobertura pela assistência social, pautadas sempre ao princípio nevrálgico da ordem constitucional, o da dignidade da pessoa humana.

Por derradeiro, foi estudado as diretrizes da assistência social que estão no artigo $5^{\circ}$ da Lei Orgânica de Assistência Social, quais sejam, descentralização político-administrativa, participação da população e primazia da responsabilidade do Estado na condução da política de assistência social.

Além disso, foi analisado os objetivos da assistência social, os quais se encontram esculpidos no artigo 203 da Constituição da República Federativa do Brasil, além de estarem definidos no artigo $2^{\circ}$ da Lei Orgânica de Assistência Social, assim como, foi verificado os principais aspectos da relação jurídica entre o Estado e os assistidos.

No segundo capítulo, foi objeto de estudo o benefício de prestação continuada da Lei n. 8.742/93 (Lei Orgânica da Assistência Social). Primeiramente 
foi realizanda uma análise sobre a evolução legislativa do benefício de prestação continuada, onde demonstrou-se seu soerguimento histórico, sendo que, com o passar dos anos, desde a promulgação da Lei Orgânica de Assistência Social LOAS na década de 90, surgiram muitas outras leis na área da Assistência Social, e com elas, várias incongruências foram sendo encontradas, as quais percebeu-se que acarretaram muitas divergências no âmbito jurídico, assim como em toda a sociedade.

Posteriormente, focou-se sobre o conceito que se deve entender acerca do benefício prestação continuada que é resguardado pela Constituição Federal a idosos (com 65 anos de idade ou mais) e a pessoas com deficiência de qualquer idade com impedimento de longo prazo, desde que estejam incapacitados para a atividade laborativa e desenvolvimento da vida independente. Por derradeiro, foi feito um estudo acerca das características do amparo assistencial.

Em fecho ao segundo capítulo, foi rebuscado o procedimento aplicado no que se refere ao requerimento do benefício assistencial, tendo em vista que foi identificado que para requerer administrativamente o benefício de prestação continuada, os idosos, devem contar com 65 anos ou mais, e as pessoas com deficiência deverão comparecer ao Instituto Nacional Seguro Social ou em uma Agência da Previdência Social - APS para constatação da deficiência.

Prosseguindo, no terceiro capítulo, perquiriu-se mais especificadamente sobre o critério de miserabilidade do benefício de prestação continuada, da Lei n. 8.742/93, o qual em estudo na doutrina e na legislação restou cristalino que o mesmo encontra-se defasado com a realidade atual da sociedade ao verificar os parâmetros trazidos pela lei para a aferição da condição de necessitado da pessoa com deficiência ou do idoso.

É importante ressaltar também, que o requisito da miserabilidade trazido pela LOAS foi considerado inconstitucional de forma incidental pelo Supremo Tribunal Federal. Por isso, os legisladores pátrios deveriam criar um outro critério condizente com a realidade social em que se vive, e que respeite os princípios mencionados acima.

Contudo, a doutrina e jurisprudência vêm admitindo a flexibilização do valor de 1/4 (um quarto) do salário mínimo, buscando criar limites que respeitem a dignidade das pessoas com deficiência e dos idosos que necessitam do benefício assistencial. 
Ademais, foi perscrutado uma comparação do critério trazido pela LOAS com outros requisitos contidos em leis assistenciais do direito brasileiro, sendo que ficou demonstrado que as demais leis trazem um requisito mais benéfico para a concessão dos outros benefícios assistenciais vigentes.

Entretanto, como visto no decorrer do trabalho, esse critério, além de não corresponder com os parâmetros para aferição de miserabilidade utilizados pelas leis assistenciais nos dias atuais, viola vários princípios constitucionais, bem como os princípios específicos da Seguridade Social, como o princípio da razoabilidade, proporcionalidade, igualdade, da solidariedade social, da justiça social e principalmente o princípio da dignidade da pessoa humana.

De mais em mais, foi realizado comentários sobre algumas implicações decorrentes da divergência de entendimento da Administração Pública, representada pelo Instituto Nacional do Seguro Social - INSS, e do Poder Judiciário sobre o requisito da miserabilidade trazido pela LOAS, sendo que, ficou demonstrado que o judiciário tem uma visão mais humanizada, onde se considera o contexto familiar integral, não focalizando apenas no critério estabelecido na Lei Orgânica de Assistência Social.

Por fim, encerrando o terceiro capítulo foi trazido ao escopo do estudo a (in)conformidade do critério do benefício de prestação continuada, qual seja $1 / 4$ do salário mínimo, com o princípio da dignidade da pessoa humana, ponto crucial dessa pesquisa.

Portanto, além de já ter sido consagrado inconstitucional o cômputo de $1 / 4$ da renda per capita para fins concessórios dos benefícios recebidos pelos idosos e portadores de deficiência, há também de se constatar que esse parâmetro para concessão do benefício viola a dignidade do indivíduo na fruição dos seus direitos fundamentais.

A inércia do Estado na comprovação de real miserabilidade provada pela situação de penúria, ainda que supere o valor defasado de renda per capita inferior a 1/4 (um quarto) do salário mínimo, exige-se atenção ao sistema constitucional na preservação da dignidade da pessoa humana como vetor finalístico concessório do benefício de prestação continuada, mais que isso, como qualidade inerente ao homem na fruição dos direitos fundamentais sociais consagrados na Constituição Federal. 
Por fim, é importante frisar mais uma vez, a importância de tal tema para a sociedade, pois afeta grande parte da população, tendo em vista o benefício assistencial não se restringir apenas às pessoas com deficiência e aos idosos. Estende-se também à todos os familiares desses indivíduos, que constituem um grupo vulnerável no país. Em decorrência disso, torna-se imprescindível que os operadores do Direito que trabalham na área da Seguridade Social, aprofundem seus conhecimentos nesse assunto, com o objetivo de tornar a atuação profissional nessa área mais humana e adequada aos princípios Constitucionais, em especial, ao princípio da dignidade da pessoa humana.

Nesse contexto, considera-se que a hipótese formulada no presente trabalho foi totalmente confirmada vez que o legislador deve reporta à Constituição e, sobretudo, observar os princípios norteadores do ordenamento pátrio, principalmente o da dignidade da pessoa humana. Contudo, demonstrou-se que o julgador deve estar ciente que a análise dos pressupostos para a concessão do benefício assistencial vão além dos limites objetivos. Dessa feita, tem-se que a análise da concessão, deve se reportar ao princípio da dignidade da pessoa humana. 


\section{REFERÊNCIAS}

AMADO, Frederico. Direito e Processo Previdenciário Sistematizado. 3. ed. Salvador: Jus Podivm, 2012.

ANDRADE, Juliana Lopes de Sousa. Breve análise acerca da Assistência Social no Brasil. Conteúdo Jurídico, Brasilia-DF: 26 dez. 2014. Disponível em: $<$ http://www.conteudojuridico.com.br/?artigos\&ver=2.51819\&seo=1>. Acesso em: 17 jun. 2017.

ABREU, Maria Aline Andrade de. A inconstitucionalidade do Critério de Miserabilidade para Concessão do Benefício de Prestação Continuada da Assistência Social. Fortaleza, 2015. disponível em: <file:///home/chronos/u5aee3fae986000eb1abc5263b9d6ba5c0a3a1834/Downloads\%20TCC.pdf>. Acesso em: 25 set. 2017.

BRASIL. Constituição da República dos Estados Unidos do Brasil. Rio de Janeiro: Sala das Sessões do Congresso Nacional Constituinte. Disponível em:

<http://www.planalto.gov.br/ccivil_03/constituicao/constituicao91.htm> Acesso em: 8 out. 2017.

Constituição da República Federativa do Brasil de 1988. Brasília:

Senado Federal. Disponível

em: <http://www.planalto.gov.br/ccivil_03/constituicao/constituicaocompilado.htm> Acesso em: 22 jan. 2017.

. Tribunal Regional Federal (4. Região). Súmula no 61, de 27 de maio de 1999. Disponível em: <https://www2.trf4.jus.br/trf4/controlador.phpacao=sumulas_trf 4>. Acesso em 19 mar. 2017.

. Turma Nacional de Uniformização (TNU). Súmula no 29. Data do julgamento: 12 dez. 2005. Disponível em: <http://www.jf.jus.br/phpdoc/virtus/sumula.php nsul=29\&PHPSESSID=62u5vd9v4fkr32j1p4q2781mh1>. Acesso em: 19 mar. 2017.

Advocacia Geral da União (AGU). Súmula no 30. Data do julgamento: 09 jun. 2008. Disponível em:< http://www.agu.gov.br/page/atos/detalhe/idato/28330>. Acesso em 19 mar. 2017.

Lei Orgânica da Assistência Social. Lei n. 8.742, de 7 de dezembro de

1993. Brasília, 7 dez. 1993. Disponível em: 
<http://www.planalto.gov.br/ccivil_03/leis/L8742compilado.htm> Acesso em: 20 jan. 2017.

Plano de Benefícios da Previdência Social. Lei n. 8.213, de 24 de julho de 1991. Brasília, 24 jul. 1991. Disponível em:

<http://www.planalto.gov.br/ccivil_03/leis/L8213cons.htm> Acesso em: 20 jan. 2017.

Regulamento de Prestação Continuada. Decreto n. 6.214, de 26 de setembro de 2007. Brasília, 26 set. 2007. Disponível em: <http://www.planalto.gov.br/ccivil_03/_ato2007-2010/2007/decreto/d6214.htm> Acesso em: 20 jan. 2017.

Altera oRegulamento do Benefício de Prestação Continuada. Decreto n. 7.617, de 17 de novembro de 2011. Brasília, 17 nov. 2011. Disponível em: <http://www.planalto.gov.br/ccivil_03/_ato2011-2014/2011/decreto/d7617.htm>. Acesso em: 8 out. 2017.

Altera oRegulamento do Benefício de Prestação Continuada. Decreto n. 8.805, de 7 de julho de 2016. Brasília, 7 jul. 2016. Disponível em: <http://www.planalto.gov.br/ccivil_03/_ato2015-2018/2016/decreto/D8805.htm>. Acesso em: 8 out. 2017.

Lei Brasileira de Inclusão da Pessoa com Deficiência. Lei nำ13.146, de 06 de julho de 2015. Brasília, 6 jul. 2015. Disponível em: <http://www.planalto.gov.br/ccivil 03/ Ato2015-2018/2015/Lei/L13146.htm> Acesso em: 20 set. 2017.

Estatuto do Idoso.Lei 10.741 de $1^{\circ}$ de outubro de 2003. Brasília, $1^{\circ}$ out. 2003. Disponível em: <http://www.planalto.gov.br/ccivil_03/leis/2003/L10.741.htm> Acesso em: 20 set. 2017.

Programa Nacional de Acesso à Alimentação. Lei n. 10.689, de 13 de junho de 2003. Brasília, 13 jun. 2003. Disponível em: <http://www.planalto.gov.br/ccivil_03/Leis/2003/L10.689.htm> Acesso em: 22 jan. 2017.

. Programa Nacional de Renda Mínima vinculada à educação - Bolsa Escola. Lei n. 10.219, de 11 de abril de 2001. Brasília, 11 abr. 2001. Disponível em:

<http://www.planalto.gov.br/ccivil_03/leis/LEIS_2001/L10219.htm> Acesso em: 22 set. 2017. 
Altera a Lei no 8.742, de 7 de dezembro de 1993, que dispõe sobre a organização da Assistência Social. Lei n. 12.435, de 6 de julho de 2013. Brasília, 6 jul. 2013. Disponível em: <http://www.planalto.gov.br/ccivil_03/_ato20112014/2011/lei/l12435.htm>. Acesso em: 8 out. 2017.

Supremo Tribunal Federal. Ação Direita de Inconstitucionalidade $\mathbf{n}$.

1.232 do Distrito Federal. Requerente: Procurador Geral da República. Requerido: Presidente da República e Congresso Nacional. Relator: Ministro Ilmar Galvão. Brasília, 27 de agosto de 1998. Disponível em:

$<$ http://redir.stf.jus.br/paginadorpub/paginador.jsp?docTP=AC\&doclD=385451>. Acesso em: 4 de out. 2017.

Supremo Tribunal Federal. Recurso Extraordinário n. 567.985 do Mato Grosso. Recorrente: Instituto Nacional do Seguro Social (INSS). Recorrido: Alzira Marcia de Oliveira Souza. Relator: Ministro Marco Aurélio. Brasília, 18 de abril de 2013. Disponível

em: http://redir.stf.jus.br/paginadorpub/paginador.jsp?docTP=TP\&doclD=4614447>. Acesso em: 4 de out. 2017.

Supremo Tribunal Federal. Recurso Extraordinário n. $\mathbf{5 8 0 . 9 6 3}$ do

Paraná. Recorrente: Instituto Nacional do Seguro Social (INSS).

Recorrido: Blandina Pereira Dias. Relator: Ministro Gilmar Mendes. Brasília, 18 de abril de 2013. Disponível em:

<http://redir.stf.jus.br/paginadorpub/paginador.jsp?docTP=TP\&doclD=4864062>. Acesso em: 4 de out. 2017.

Supremo Tribunal Federal. Reclamação 4374 - LOAS -

Benefício Assistencial (2005.83.20.009801-7). Recorrente: Instituto Nacional do Seguro Social (INSS). Recorrido: Turma Recursal dos Juizados Especiais Federais do Estado de Pernambuco. Relator: Ministro Gilmar Mendes. Brasília, 18 de abril de 2013. Disponível em:

<http://redir.stf.jus.br/paginadorpub/paginador.jsp?docTP=TP\&doclD=4439489> . Acesso em: 4 de out. 2017.

Tribunal Regional Federal (4ำ Região). Apelação Cível n. 0001469-

15.2017.4.04.999/RS. Apelante: INSS-Instituto Nacional do Seguro Social. Apelado: Lia Mara Lacerda Fernandes. Relator: Desembargadora Federal Taís Schilling Ferraz. Porto Alegre, 9 de maio de 2017a. Disponível em: <https://jurisprudencia.trf4.jus.br/pesquisa/resultado_pesquisa.php>. Acesso em: 8 out. 2017.

Tribunal Regional Federal (1ํㅡㄹ Região). Apelação Cível n.004079135.2016.4.01.9199/MG. Apelante: Aline Bueno Ribeiro (menor). Apelado: INSSInstituto Nacional do Seguro Social. Relator: Desembargador FederalCésar Cintra 
Jatahy Fonseca. Brasília, 9 de novembro de 2016. Disponível em: http://arquivo.trf1.jus.br/PesquisaMenuArquivo.aspp1 $=407913520164019199 \& p A=\&$ $\mathrm{pN}=407913520164019199$ > . Acesso em: 8 out. 2017.

Tribunal Regional Federal ( $2^{\circ}$ Região). Apelação Cível n. 0002203-

54.2016.4.02.9999/RJ. Apelante: INSS-Instituto Nacional do Seguro Social. Apelado: Celina da Costa Soares dos Santos. Relator: Desembargador Federal Paulo Espirito Santo. Rio de Janeiro, 16 de março de 2017b. Disponível em:

<http://www10.trf2.jus.br/portal/movimento=cache\&q=cache:K_OikQx06tlJ:acordaos. trf2.jus.br/apolo/databucket/idx\%3Fprocesso\%3D201699990022031\%26coddoc\%3D 621054\%26datapublic\%3D20170330\%26pagdj\%3D87/110+\&site=v2 jurisprudencia \&client $=v 2$ index\&proxysty lesheet $=v 2$ index\&lr=lang_pt\&ie $=U T F$ 8\&output=xml_no_dtd\&access=p\&oe=UTF-8>. Acesso 8 out. 2017

Superior Tribunal de Justiça. Agravo em Recurso Especial $\mathbf{n}$.

319.880/PR. Agravante: INSS-Instituto Nacional do Seguro Social. Agravado: Isabel Fernandes Bologna. Relator: Ministro Napolẽao Nunes Maia Filho. Brasília 9 de maio de 2017c. Disponível em: <http://www.stj.jus.br/SCON/decisoes/toc.jsp livre=319.889\&\&b=DTXT\&thesaurus=JURIDICO\&p=true $>$. Acesso em 8 out. 2017.

. Previdência Social. Benefício assistencial ao idoso e à pessoa com deficiência (BPC). 2017c. Brasília. Disponível em <http://www.previdencia.gov.br/servicos-ao-cidadao/todos-os-servicos/beneficioassistencial-bpc-loas/> Acesso em: 21 abr. 2017.

BERCLAZ, Márcio Soares. Algumas considerações sobre o princípio do interesse público no âmbito do Direito Administrativo.Teresina, ano 7, n. 60, 1 nov. 2002. Disponível em: <http://jus.uol.com.br/revista/texto/3545>. Acesso em: 15 jun 2017.

BOBBIO, Noberto. Teoria da Norma Jurídica.3 ed. rev. São Paulo, 2005.

CANOTILHO, J. J. Gomes. Direito constitucional e teoria da Constituição. 2. ed. Coimbra: Almedina, 1998.

CASTRO, Carlos Alberto Pereira de; LAZZARI, João Batista. Manual de direito previdenciário. 19 ed. Rio de Janeiro: Forense, 2016.

FERREIRA, Lauro Cesar Mazzeto. Seguridade Social e Direitos Humanos. São Paulo: LTR, 2007. 
FONSECA, Ricardo Tadeu Marques da. O Novo Conceito Constitucional de Pessoa Com Deficiência: Um Ato De Coragem. In: FERRAZ, Carolina Valença et al. (Coord.). Manual dos Direitos da Pessoa com Deficiência. Edição Digital. São

Paulo: Saraiva, 2012.

GOIÁS. Ministério Público do Estado. Histórico da Política de Assistência Social. Texto produzido para a Capacitação Regional de Conselheiros Estaduais e Municipais de Assistência Social. Agosto de 2000. Disponível em:

$<$ http://www.mp.go.gov.br/portalweb/hp/41/docs/historico_da_politica_de_assistencia _social___2000.pdf>. Acesso em: 20 jan. 2017.

HORVARTH JÚNIOR, Miguel. Direito Previdenciário. 9. ed. São Paulo:

QuartierLatin, 2012.

IBRAHIM, Fábio Zambitte. Curso de direito previdenciário. 22 ed. Niterói: Impetus, 2016.

LOPES, Felipe Mota. O Requisito da Miserabilidade do Benefício de Prestação Continuada da Lei n. 8.742/93 (Lei Orgânica de Assistência Social). João Pessoa, UFPB. 2014. Disponível em:

<http://rei.biblioteca.ufpb.br/jspui/bitstream/123456789/854/1/FML08012015.pdf>. Acesso em: 12 ago. 2017.

KERTZMAN, Ivan. Curso prático de direito previdenciário. 12 ed. Salvador: JusPodivm, 2015.

MARTINEZ. Wladimir Novaes. Curso de direito previdenciário. Noções de direito previdenciário. 4. ed. São Paulo: LTr, 2015a.

Wladimir Novaes. Princípios de direito previdenciário. 9. ed. São Paulo: LTr, 2015b.

MARTINS, Sergio Pinto. Direito da seguridade social. 36. ed. São Paulo: Saraiva, 2016.

MENDES, G. F.; BRANCO, P. G. G. Curso de direito constitucional. 9. ed. São Paulo: Saraiva, 2014.

MEIRELLES, Hely Lopes. Direito administrativo brasileiro. 32. ed. São Paulo: Malheiros, 2006. 
MORAES, Alexandre de. Direito Constitucional. 32. ed. São Paulo: Atlas, 2016.

NOVELINO, Marcelo. Manual de direito constitucional.8 ed. Rio de Janeiro:

Forense; São Paulo: Método, 2013.

NERY JÚNIOR, Nelson. Princípios do Processo Civil na Constituição Federal. 8. ed. São Paulo: Revista dos Tribunais, 2004.

PIETRO, Maria Sylvia Zanella di. Direito Administrativo. 19. ed. São Paulo: Atlas, 2006.

PIOVESAN, Flávia. Direitos humanos e o direito constitucional internacional. In:

Caderno de direito constitucional. Módulo V. Escola da Magistratura do Tribunal Regional Federal da 4⿳亠丷a Região, Porto Alegre, n. 44, 2006. Disponível em:

$<$ https://www2.trf4.jus.br/trf4/upload/arquivos/emagis_atividades/ccp5_flavia_piovesa n.pdf>. Acesso em: 28 set. 2017.

SARLET, Ingo Wolfgang. Dignidade da pessoa humana e direitos fundamentais na Constituição Federal de 1988. 9. ed. 2 tiragem. Porto Alegre: Livraria do Advogado, 2012.

SANTOS, Marisa Ferreira dos. Direito previdenciário esquematizado. São Paulo: Saraiva, 2016.

SILVA, José Afonso. Curso de Direito Constitucional Positivo. 32. ed. São Paulo: Editora Malheiros, 2010.

SOUZA, Lilian de Castro. Direito previdenciário. Série leituras jurídicas: provas e concursos. v. 27. 4. ed. São Paulo: Atlas, 2016.

TAVARES, Marcelo Leonardo. Direito previdenciário: regime geral de previdência social. 15. ed. Ver. E atual. Niterói: Impetus, 2014.

TAKAMORI, Claudia Brabo. A dignidade da pessoa humana como vetor finalístico do benefício de prestação continuada. Marília. 2014. Disponível em: <http://aberto.univem.edu.br/bitstream/handle/11077/1172/A\%20DIGNIDADE\%20DA \%20PESSOA\%2OHUAMAN\%20COMO\%20VETOR\%20FINAL\%C3\%8DSTICO $\% 20$ DO\%20BENEF\%C3\%8DCIO\%20DE\%20PRESTA\%C3\%87\%C3\%83O\%20CONTIN UADA.pdf? sequence=1>. Acesso em: 12 ago. 2017. 
TAVARES, Marcelo Leonardo. Direito Previdenciário: regime geral de previdência social e regras constitucionais dos regimes próprios de previdência social. 15. ed. rev. atual. Niterói: Impetus. 2014.

VENOSA, Sílvio de Salvo. Direito Civil: parte geral. 11. ed. São Paulo: Atlas, 2015. 